\title{
Recent developments in methicillin- resistant Staphylococcus aureus (MRSA) management and potential antimicrobial alternatives to combat the antibiotic resistance challenge: A review
}

\author{
Saleha Mahnoor Faheem ${ }^{1}$, Umar Farooq Gohar ${ }^{1}$ and Sidra Riaz ${ }^{1^{*}}$ \\ 1. Institute of industrial Biotechnology GC University Lahore-54000, Pakistan \\ *Corresponding author's email: riazsidra585@gmail.com \\ Citation
}

Saleha Mahnoor Faheem, Umar Farooq Gohar and Sidra Riaz. Recent Developments in Methicillin-Resistant Staphylococcus aureus (MRSA) management and potential antimicrobial alternatives to combat the antibiotic resistance challenge: A review. Pure and Applied Biology. Vol. 11, Issue 2, pp353-385.

http://dx.doi.org/10.19045/bspab.2022.110037

\begin{tabular}{llll}
\hline \hline Received: 12/04/2021 & Revised: 19/06/2021 & Accepted: 29/06/2021 & Online First: 28/07/2021 \\
\hline \hline
\end{tabular}

\section{Abstract}

The global emergence of Methicillin-resistant Staphylococcus aureus (MRSA) strains is causing a serious increase in mortality and morbidity rates both in hospitals and in community settings. The high incidence of MRSA associated bacteremia can potentially cause infective endocarditis, septic arthritis, osteomyelitis and complications such as septic shock which are becoming a high challenge for clinicians to treat. The multi-resistance acquisition of MRSA against currently available antibiotics has significantly reduced their efficacy against related infections. To overcome this global health concern of the rapidly spreading antibioticresistance phenomenon among bacterial pathogens, particularly MRSA, implementation of effective management strategies and the need for rapid identification and practical application of potential antimicrobial alternatives has become crucial. Herein, we have provided a brief description of potential antimicrobial alternatives i.e., phytochemicals from plant extracts, bacteriocins, antimicrobial peptides, bacteriophage therapy, nanoparticles and some other approaches that can be used as monotherapy or in combination with currently effective antibiotics to combat MRSA infections. An overview of MRSA infections and developments in MRSA management has also been presented in the initial section of this review.

Keywords: Antibiotic-resistance; Antimicrobial alternatives; Bacteremia; Nosocomial infections; Phytochemicals, Staphylococcus aureus

\section{Introduction}

Staphylococcus aureus is a leading nosocomial Gram-positive bacterium and responsible for several infectious diseases such as bacteremia, pneumonia, endocarditis, skin infections, and food poisoning [1]. Originally, Staphylococcus aureus ( $S$. aureus) was thought to be a major nosocomial pathogen but epidemiologically different clones have also been identified in community settings [2].

S. aureus has developed resistance against multiple antibiotics which makes this bacterium a challenging pathogen to treat [3]. Therefore, $S$. aureus is termed methicillin-resistant Staphylococcus aureus (MRSA) which is highly resistant to 
methicillin and causes high morbidity, high mortality rate, and expensive treatment approaches [4]. Vancomycin was a standard drug to treat MRSA for years but bacteria also have developed resistance against it and restricted its clinical efficacy [5].

Nosocomial infections present a serious threat to patients globally. The decision and timing of antibacterial treatment extraordinarily influence treatment results in MRSA [6]. For $S$. aureus infection, $\beta$ lactam treatment is viewed as the highest quality standard to treat infection [7]. The 2011 Infectious Diseases Society of America rules suggest treatment with vancomycin or daptomycin for MRSA [8]. Nonetheless, every antimicrobial formulation has restrictions [9]. Many cases reported that the utility of vancomycin possesses slow bactericidal activity, low tissue penetration, and increasing findings related to resistance and failure [10]. Although, Daptomycin was found to be effective against MRSA bacteremia treatment-emergent nonsusceptibility is concerning and experimental evidence showed that prior vancomycin treatment may facilitate daptomycin resistance in $S$. aureus [11].

Given the significant morbidity and mortality related to MRSA and the limits of presently affirmed treatments, there is a need to explore different approaches and agents for the treatment of MRSA bacteremia [12]. Time to efficacious treatment is to a great extent reliant on the identification of the pathogen. Delays in the identification of pathogen lead to ineffective clinical results [13]. Standard microbial recognition procedures take somewhere in the range of 48 and 72 hours, while advanced methods which have been developed recently give fast results within 3 hours of sample collection [14]. By adopting advanced identification techniques, optimized antibacterial therapy, fast diagnostic procedures may bring down mortality, hospitalization, and expenses.

\section{Prevalence}

The predominance of MRSA infections, particularly bacteremia, varies around the globe. In 2014, the population-weighted mean of Europe was $17.4 \%$ in Netherlands and Romania, and the percentages of invasive MRSA isolates were from $0.4 \%$ in the Netherlands to 56\% in Romania. A high proportion of resistant isolates of MRSA prevail in southern countries in the Europe region. Invasive $S$. aureus isolates of MRSA in Europe have decreased over time but 7 of the 29 European Union countries still report more than $25 \%$ of MRSA isolates [13].

An analysis of 15 studies reports that in the range of 13 to $74 \%$ of global S. aureus infections are MRSA [17]. Publications and national surveillance data from the countries of South and East Asia and the Western Pacific identify $S$. aureus as an important pathogen, with MRSA infections ranging from 2.3 to $69 \%$ [18]. In 2005, a survey conducted in the US reported that the rate of invasive MRSA infections was 31.8 per 100,000 individuals after adjustment for gender, age, and race, and from this data, it was deduced that $75 \%$ of these MRSA infections involved $S$. aureus bacteremia [19]. The percentage of rate of MRSA bacteremia is higher than the rate of MRSA bacteremia in Canada, where from 2000 to 2004 the rate of infection was 2.1, 3.6, and 1.6 per 100,000 individuals for Calgary, Sherbrook, and Victoria [20]. In Europe, from 2011-2012, $12.3 \%$ of all healthcare-associated infections were due to $S$. aureus. More than $60 \%$ of healthcareassociated infections were caused by $S$. aureus in Italy, Cyprus, Romania, and Portugal [21].

The source of MRSA infections-hospital acquired, community-acquired, or healthcare-associated community-onsethas been evolving. The rate of invasive MRSA cases in the US has been going down (Fig. 1) [21, 22], with healthcareassociated community onset-infections currently being the major cause of MRSA infections. Patients with healthcare- 
associated community-onset MRSA infections often have complications, for example, diabetes, decubitus, ulcers, renal sickness, earlier stroke, or dementia [23].

Information from Canada, Australia, and Scandinavia show an increase in the percentage of MRSA bacteremia in the years 2000 to 2008, principally brought about by an increment in communityacquired infections.

In Pakistan, staphylococcal infections are identified and most of them are resistant infections (MRSA). In one study, a total of 350 staphylococcal clinical specimens were obtained out of which 194 were found out to be methicillin-resistant Staphylococcal aureus (MRSA) infections [24]. In one more study, 280 clinical specimens of $S$. aureus were taken out of which $36 \%$ were identified as MRSA. S. aureus infection was more prevalent among 50-59 years age group patients (Table 1) [25].

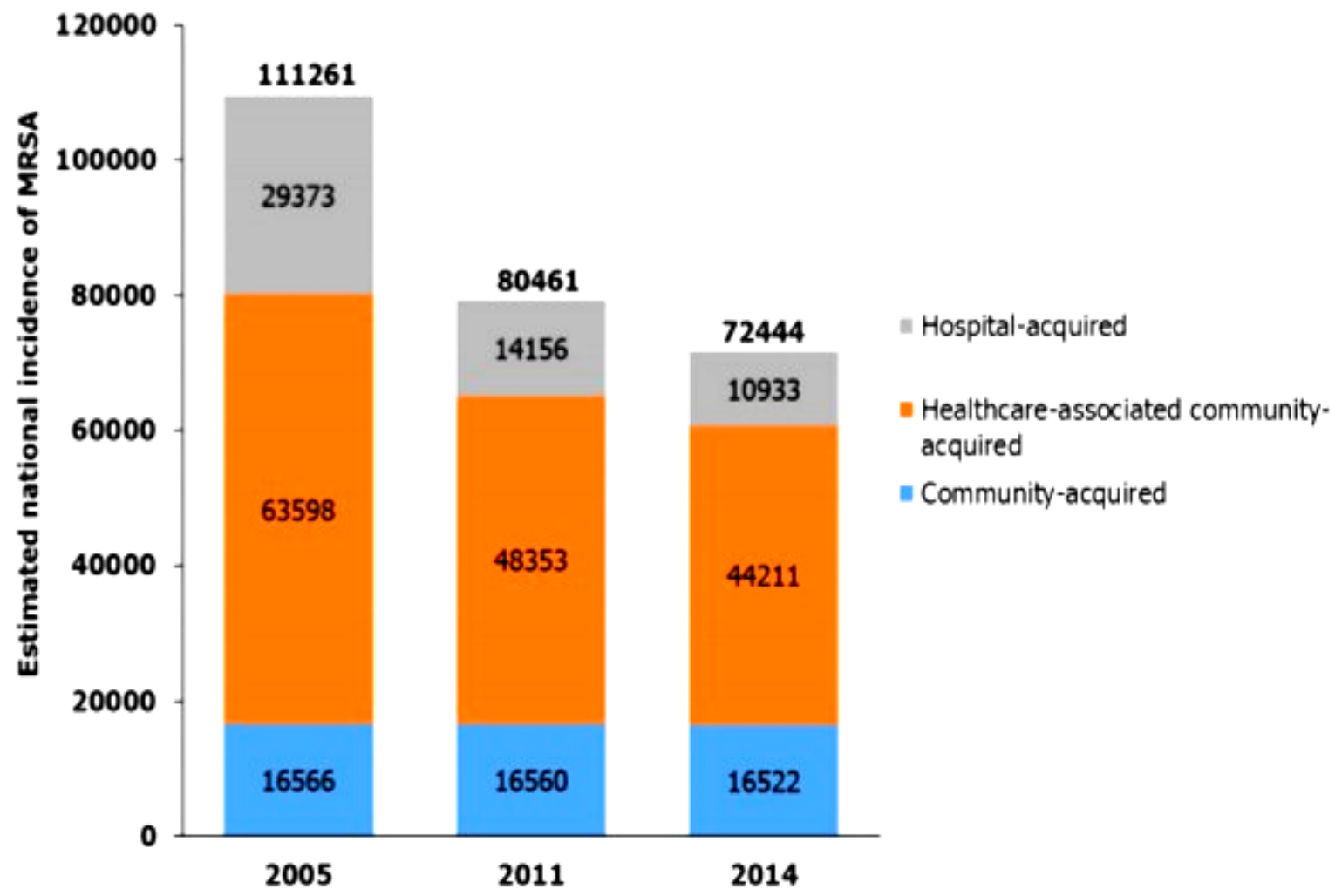

Figure 1. The public assessed number of MRSA related infections in the United States (US), separated by disease setting. Adjusted from information revealed by the Center for Disease Control and Prevention [21]

Table 1. Studies of clinical specimens of MRSA in Pakistan

\begin{tabular}{|c|c|c|c|c|}
\hline Study & Location & Specimens analyzed & Specimens proved to be MRSA & References \\
\hline 1 & Rawalpindi & 350 & $55 \%$ & {$[24]$} \\
\hline 2 & Peshawar & 280 & $36 \%$ & {$[25]$} \\
\hline
\end{tabular}

Infections caused by Staphylococcus aureus

Staphylococcus aureus infects the skin, soft tissue, respiratory tract, bones, joints, and endovascular system [26]. The debate beneath is restricted to perilous staphylococcal infections. Most of these infections happen in people with various peril factors for infection. A more definite debate on the clinical signs of 
staphylococcal infections can be found in a few late reports [27].

\section{Bacteremia}

Staphylococcal bacteremia cause 11 to $43 \%$ deaths [28]. Several factors are associated with increased mortality including the age of more than 50 years, eradicable foci of infection, and life-threatening underlying respiratory, cardiac, and neurologic disease. Methicillin-resistant strains causing bacteremia are not associated with an increased death rate. The change in the Acute Physiology and Persistent Health Evaluation (APACHE) score from the day preceding to the day of $S$. aureus bacteremia was as of late found to foresee the clinical course and outcome [29]. Staphylococcal bacteremia causes a high frequency of complications, ranging from 11 to $53 \%$. Patients with bacteremia who do not have endocarditis can develop metastatic infection [30].

Catheterization is associated with an increased level of staphylococcal bacteremia [31]. The frequency of complications is lower for catheter-related infections than for all other causes of bacteremia $(24 \%)$, similar to the general death rate $(15 \%)$ [32]. Patients with bacteremia or fever that endures for more than 72 hours after the catheter has been taken out may have a high level of complications [33]. The rate of endocarditis in patients with catheters, assessed based on clinical signs, is likewise low, extending from 0 to $18 \%$. Some examinations, in any case, propose that the occurrence of endocarditis might be higher. Twenty-five percent of chose patients with staphylococcal bacteremia (26 of 103) and $23 \%$ of those with catheters as the essential center had trans-esophageal echocardiographic proof of endocarditis without clinical or transthoracic echocardiographic findings $[34,35]$.

\section{Endocarditis}

$S$. aureus endocarditis has increased with time and now 25 to $35 \%$ of patients get infected by it [36]. People which take intravenous drugs, aged patients, and hospitalized patients with prosthetic valves are at high risk to contract $S$. aureus endocarditis. In all three groups, the initial symptoms are only limited to malaise and fever, which make diagnosis difficult. Usually, endocarditis is not much fatal disease but $S$. aureus endocarditis cause rapid onset of high fever involves cardiac valves and the loss of physical stigmata [37]. In one study, $13 \%$ of patients with febrile intravenous drug users were admitted to an emergency room and the diagnosis could not be done based on available laboratory data [38].

Intravenous drug users have right-sided endocarditis and the patients are young and the death rate among them is very low. Intravenous drug users with Human Immunodeficiency Virus (HIV) infection have a poor prognosis as compared to patients without HIV infection [39]. Patients who do not use drugs have leftsided endocarditis and these patients are old and the mortality rate is high among them [40]. A study states that embolic and neurologic complications are common in left-sided S. aureus endocarditis.

aureus is quite possibly the most wellknown pathogen in nosocomial and prosthetic-valve endocarditis, and intravascular catheters are the most regular source of bacterial inoculation. The death rate for nosocomial endocarditis, paying little mind to the microbe, is 40 to $56 \%$, and the rate is considerably higher when the microbe is $S$. aureus [41]. In a large number of these cases, the conclusion is clouded by different conditions or the administration of anti-microbials. Prosthetic-valve endocarditis, particularly in the early postoperative period, is frequently fulminant and is portrayed by the formation of myocardial abscesses and the development of valvular scarcity. Forty-three percent frequency of endocarditis in patients with prosthetic valves who had nosocomial bacteremia, the most involved bacterium was $S$. aureus [42]. 


\section{Metastatic infections}

Staphylococcus aureus tends to spread to specific locations, including the bones, joints, kidneys, and lungs. Suppurative samples collected from these locations of infections are the source of potential foci for repetitive infections. Patients who have constant fever conditions even after taking proper treatment should be evaluated for the presence of suppurative locations in the body.

\section{Sepsis}

Few bacteremic or local infections can lead to sepsis. Old age, immunosuppression, chemotherapy, and invasive clinical procedures are the risk factors for sepsis. Staphylococcal sepsis includes fever, hypotension, tachypnea, and tachycardia. S. aureus is a gram-positive pathogen and it is the most common one in the cases of sepsis [43]. If the sepsis leads to a severe condition then infection can progress to dysfunctioning of many organs, intravascular coagulation, lactic acidosis, and ultimately death [43]. In both grampositive and gram-negative sepsis, the degrees of flowing tumor necrosis factoralpha, interleukin-1, as well as, interleukin6 are prescient of the outcome [44].

\section{Toxic shock syndrome}

Several cases of staphylococcal toxic shock syndrome were reported from 1980 to 1981 due to the use of superabsorbent tampons during menstruation. The disease is characterized by a sudden onset, frequently in formerly healthy persons. Staphylococcal toxic shock syndrome includes multiorgan damage, hypotension, high fever, and erythematous rash. The toxic shock syndrome develops from a site of colonization as opposed to infection [45]. $90 \%$ of cases are related to menstruation but $50 \%$ of cases are unrelated to menstruation (Table 2). One-third of total cases are nonmenstrual and also these cases are increasing. These nonmenstrual cases are associated with localized infections, surgery, or insect bites. Patients with nonmenstrual toxic shock syndrome have a higher death rate than those with menstrual toxic shock syndrome [46].

Table 2. Comparison of rate of infection, mortality rate and signs and symptoms of $S$. aureus infections

\begin{tabular}{|c|c|c|c|c|}
\hline Infections & $\begin{array}{c}\text { Incidence of } \\
\text { infection }\end{array}$ & $\begin{array}{c}\text { Mortality } \\
\text { rate }\end{array}$ & Signs and symptoms & References \\
\hline Bacteremia & $11-53 \%$ & $11-43 \%$ & $\begin{array}{c}\text { Fever, skin rashes and fast heart } \\
\text { rate }\end{array}$ & {$[\mathbf{3 0}]$} \\
\hline Endocarditis & $25-35 \%$ & $>40-56 \%$ & $\begin{array}{c}\text { Malaise, fever and loss of physical } \\
\text { stigmata }\end{array}$ & {$[37]$} \\
\hline $\begin{array}{c}\text { Metastatic } \\
\text { infections }\end{array}$ & $11-53 \%$ & $11-43 \%$ & As for bacteremia & {$[\mathbf{3 0}]$} \\
\hline Sepsis & $20-25 \%$ & $10-30 \%$ & $\begin{array}{c}\text { Fever, hypotension, tachypnea and } \\
\text { tachycardia }\end{array}$ & {$[\mathbf{4 3}]$} \\
\hline $\begin{array}{c}\text { Toxic shock } \\
\text { syndrome }\end{array}$ & $39 \%$ & $3-5 \%$ & $\begin{array}{c}\text { Multi organ damage, hypotension, } \\
\text { high fever, erythematous rash }\end{array}$ & {$[\mathbf{4 5}]$} \\
\hline
\end{tabular}

\section{Development of antibiotic resistance in MRSA}

Methicillin is known to put forth its antimicrobial activity by preventing the cross-linking of peptidoglycan via inhibition of transpeptidase enzyme's activity. It does so, by first binding with cell-wall's Penicillin binding proteins
(PBPs) [47]. However, MRSA has adopted ways to prevent itself from methicillin's lethal action, MRSA strains are now identified based upon their acquisition of mecA gene which is present on staphylococcal cassette chromosome mec (SCCmec). This mecA gene is responsible for expression PBP2 homolog protein 
known as PBP2a or PBP2'. Atleast 6 different types of mecA gene have been reported [48, 49]. SCCmec region is incorporated into the $S$. aureus chromosome at a specific position (attBsc), located nearby orfX region (near the origin of replication) [50]. Based upon the type of SCCmec, this DNA fragment can range in size from $21-67 \mathrm{~Kb}$ [49]. There is a constant rapid increase in discovery of new types of SCCmec region in MRSA chromosome, currently 11 types have been found. Surprisingly, all types contain low-affinity (for beta-lactams) possessing PBP2a gene, mecA.

Expression of mecA gene is generally inducible and regulated by $\mathrm{mecl}$, mecRl and other genes like blaI, blaRl, femB, aux [51]. The mecA gene encoded PBP2a has low affinity for $\beta$-lactams due placement of its active site in a deep location not accessed by methicillin and other $\beta$-lactams antibiotics as a result of this, resistance is attained against Methicillin [52]. A pictorial representation of mechanism of mecA gene activation is shown (Fig. 2). SCCmec DNA region is also found to contain $\mathrm{ccr}$ genes that are responsible for amalgamation and excision from the chromosome and aid in mobility of element [49, 50]. Other regions of SCCmec may vary depending upon the particular type, but some of them contain additional resistant genes against other antibiotics [52]. In a novel research finding this region is also found to harbor virulent gene, Psm-mec, that encodes peptide toxin and is located in close proximity to mecA gene in different SCCmec types [53]. From a drug-discovery perspective it is logical to synthesize alternatives (small moleculeinhibitors) that work in synergy with $\beta$ lactams for particularly targeting mecA and associated fern (factors essential for the expression of methicillin-resistance) genes expression. One such report regarding efficiency of synthetic tripeptide, LY301621 have also appeared in which it is found to potentiate the activity of methicillin against MRSA strain [54].

\section{Recent developments in MRSA management}

MRSA infections are frequently prevailing in our societies affecting and killing many people of different age groups worldwide. Most of the infections which are a risk to the community are blood infections (bacteremia) which is a more threatening and more lethal condition. Since MRSA infections are more frequent in old people so there is a need to control infection by efficient management in the community as well as in hospitals for that old people are more susceptible to infections due to their weak immunological state. Efficient management in hospitals includes effective measures to prevent contact transmission of infections, rapid and effective methods to diagnose and detect infections, and to treat infections by antimicrobial alternatives to combat resistance issues as shown in the below flow chart (Fig. 3). 


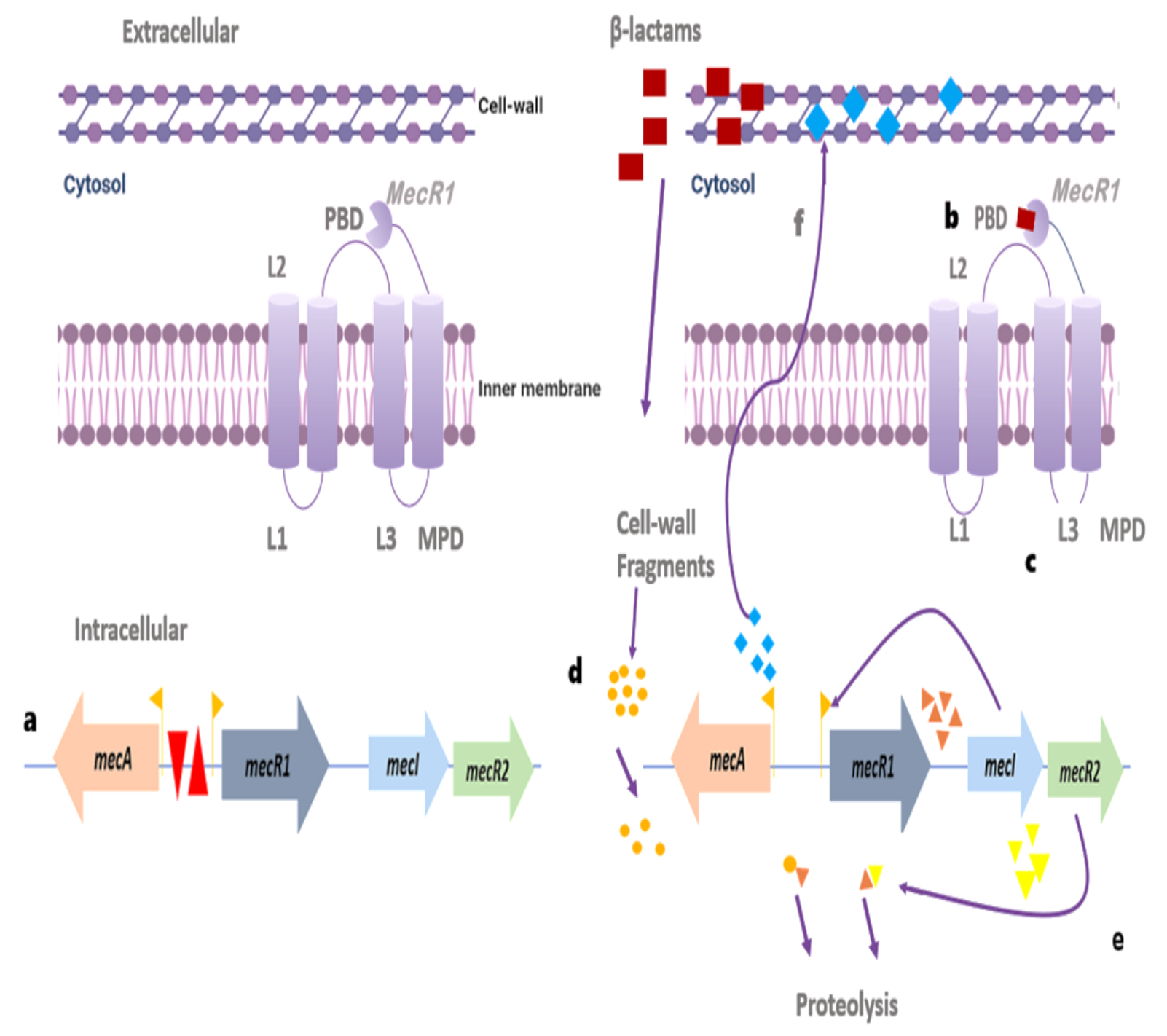

Figure 2. Schematic overview of regulation of mecA gene in MRSA. a) In absence of $\beta$ lactams mec operator is inactivated by binding of repressor protein mecI to its promotor site. b) $\beta$-Lactams are detected in external environment by their binding to the penicillinbinding domain (PBD) of MecR1 Protein. c) This binding triggers the activation of the intracellular metalloproteinase domain (MPD) (L3) of MecR1 protein. Whether this activation directly lead to proteolytic degradation of MecI repressor protein is unclear. d) B-lactams induced disruption of cell-wall biosynthesis leads to formation of cell-wall fragments in cytoplasm that act as co-activator and disrupt association of mecI repressor protein with mec operator and performs its proteolytic degradation. e) B-lactams also induce transcription of mecR2 gene that form another repressor protein MecR2, that also binds to Mec I, leading to its proteolysis. (f) Ultimately, through proteolytic activities of these three degradation mechanisms, MecI induces transcription of mecA, that causes PBP2a production (having lower affinity for $\beta$-lactams), hence the expression of methicillin resistance is executed 


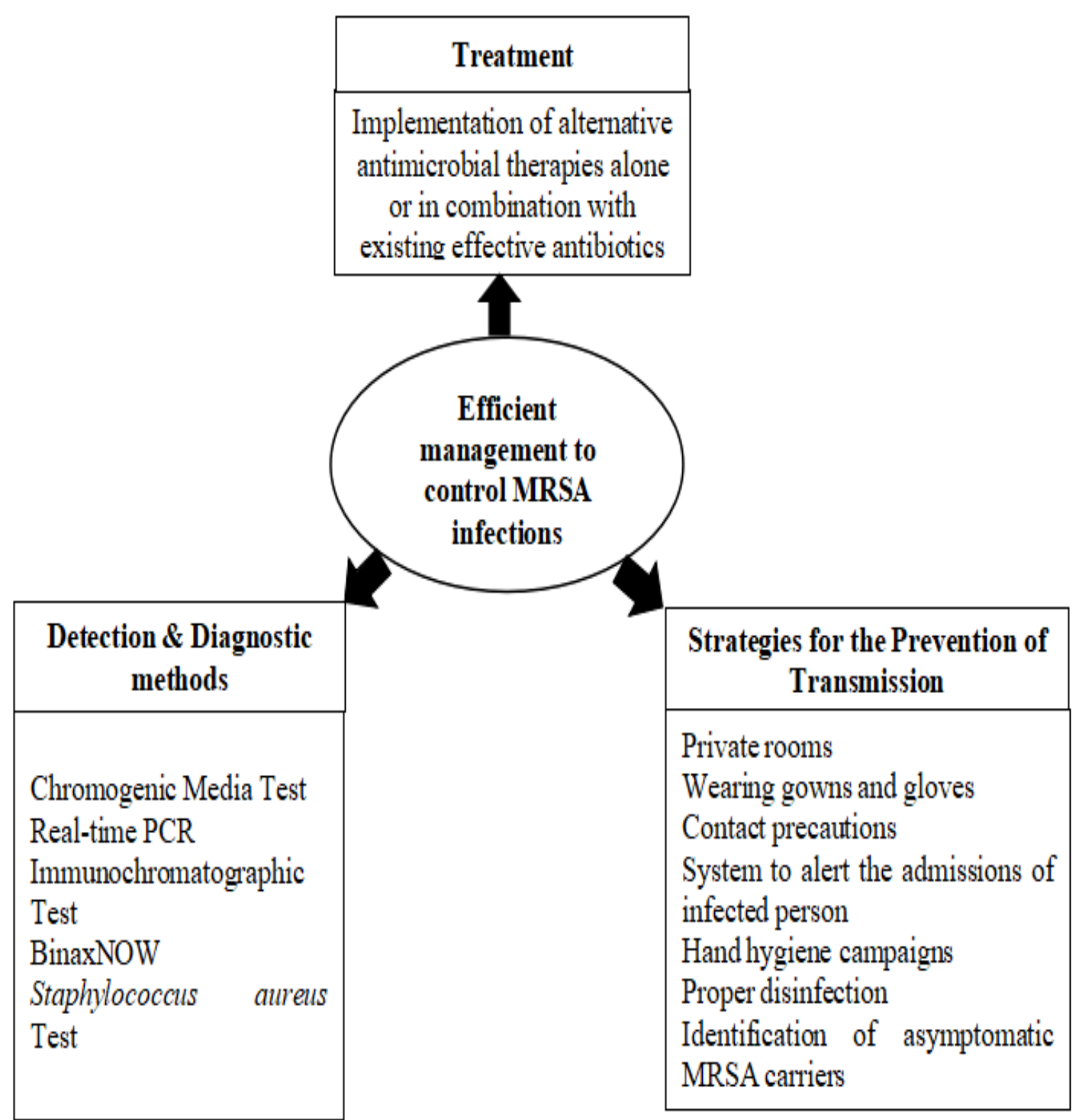

Figure 3. Management system for effective control of MRSA related infections

Advancements in detection and diagnosis methods

Identification of causative agents for infections can be very difficult and challenging when the strains involved are resistant as in the cases of MRSA. Old cultural techniques and susceptibility testing methods are too much timeconsuming and take between 48 and 72 hours to conclude a decision [16]. The time to detect MRSA has been greatly reduced by the development of advanced molecular and nonmolecular testing approaches [16]. These techniques are rapid and effective to control infections and decrease costs. Rapid tests for MRSA are low cost and reduce the length of stay of the patient in the hospital. In this way, identification can happen rapidly and the switch from empiric to targeted therapy can be 1.6 days shorter. Rapid molecular tests for diagnosis can also reduce the rate of mortality among patients with bacteremia [55]. Rapid molecular testing and antibiotic management program should be collaborated to further decrease the risk of mortality [55]. There should be a proper management system [15] in every hospital to consider the factors like 
specificity, sensitivity, price, turnaround time, and proficiency needed for each test [56]. The (Table 3) presents a comparison of tests that can be used to detect and diagnose MRSA more efficiently and rapidly.

\section{Chromogenic media tests}

Advancement to the old cultural techniques is the use of chromogenic agar, which involves the production of color in bacterial cultures [16]. Chromogenic media involves the use of antibiotics which only allow the resistant bacteria to grow and flourish [16]. By this method, MRSA can be detected within 20 to 26 hours. A series of experiments showed that the sensitivity of the test was $78.3 \%$ after 18 to 24 hours and it was increased after 48 hours, specificity of the test was $97 \%$ at 18 to 24 hours and it was decreased by $94 \%$ after 48 hours. Both sensitivity and specificity factors of the test were higher than the traditional culture methods. Chromogenic media test has also reduced the time by 12 hours to treat MRSA [57].

\section{Real time polymerase chain reaction (PCR)}

Another important molecular technique in the detection of MRSA is the real-time polymerase chain reaction (PCR) test. PCR test can detect genes that are specific to $S$. aureus [16]. PCR test targets a portion of DNA where the SCCmec gene responsible for MRSA meets the $S$. aureus orfX gene [16]. Samples for PCR test can be taken from blood or a nasal or wound swab and the test can be performed directly on these samples giving the results within only 1 to 3 hours [16]. Although the PCR test is very rapid as compared to other tests but time is required to transport samples, perform the test and deduce the results [58]. Nevertheless, the overall time required to run the PCR test is much shorter as compared to the chromogenic media test [58]. The sensitivity and specificity for PCR are $92.5 \%$ and $97 \%$, respectively [56]. The sensitivity of PCR is significantly higher than that of the chromogenic media test, and specificity is significantly higher than that of old cultural methods [56].

\section{Immunochromatographic test}

The immunochromatographic test is another detection approach for MRSA. In this test, antibodies that are specific for bacterial proteins, bind to these proteins and produce color in the test medium. An example of an immunochromatographic test is the latex agglutination test. This test involves the use of a monoclonal antibody against a protein (PBP2a) produced by the mecA gene [59]. Firstly, the latex particles are sensitized by the antibody and then they are allowed to react with PBP2a and they clump together showing agglutination [16]. The sensitivity and specificity for this test are $97 \%$ and $100 \%$, respectively [60]. Another PBP2a antibody test showing 97\% sensitivity and $100 \%$ specificity [60], includes fewer steps than the latex agglutination test [61]. This test takes under 6 minutes to complete, and results show up as hued lines on test strips [61].

\section{BinaxNOW Staphylococcal aureus test}

The BinaxNOW Staphylococcus aureus Test detects $S$. aureus and helps to escape from false-positive results. The time required for this test is less than 30 minutes, sensitivity is $95.8 \%$ and specificity is 99.6\%. This test is not specific for MRSA but it can eliminate out other staphylococci. Because of the minimal cost and speed of results, it could be a valuable test to perform before sending tests for PCR testing [59]. 
Table 3. Comparison of tests and techniques which can be used to detect and diagnose MRSA more efficiently and rapidly

\begin{tabular}{|c|c|c|c|c|c|}
\hline S. No. & Tests and teachniques & Detection time & Sensitivity & Specificity & References \\
\hline $\mathbf{1}$ & Chromogenic media test & $20-26$ hours & $86 \%$ & $95 \%$ & {$[\mathbf{5 7}]$} \\
\hline $\mathbf{2}$ & Real time PCR & $1-3$ hours & $92 \%$ & $97 \%$ & {$[\mathbf{5 6}]$} \\
\hline $\mathbf{3}$ & $\begin{array}{c}\text { Immunochromatographic } \\
\text { test }\end{array}$ & $>30$ minutes & $97 \%$ & $100 \%$ & {$[\mathbf{6 0}]$} \\
\hline $\mathbf{4}$ & $\begin{array}{c}\text { BinaxNOW Staphylococcal } \\
\text { aureus test }\end{array}$ & $<30$ minutes & $95.8 \%$ & $99.6 \%$ & {$[\mathbf{5 9}]$} \\
\hline
\end{tabular}

\section{Potential antimicrobial alternatives to combat the MRSA antibiotic resistance crisis}

The development of the first antibiotic penicillin in 1929 significantly raised the quality and probability of human life. Later on, a number of effective antibiotics were produced against previously lethal bacterial infections. Thus, about a half-century ago, antibiotics significantly brought a golden revolution in the medicine field. But unfortunately, an unregulated and careless attitude towards over antibiotic utilization into medicine, agricultural, aquaculture, poultry and veterinary medicine practices has brought disastrous side-effects in the form of world-wide emergence of the multiple drug resistance (MDR) and extensively drug-resistant (XDR) clinical strains. The antibiotic resistance even against core and potent antibiotics has brought us towards the beginning of the post-antibiotic era where millions of lives are being threatened and suffering, morbidity, and mortality rates are continuing to increase.

The widespread presence of MRSA in hospital-settings, community, and food and feed sectors is raising life-threatening concerns. The first case of MRSA emerged in 1961 during the clinical use of "Methicillin" against Penicillin-resistant S.aureus. Surprisingly, resistance against Methicillin was developed within 1 year of its first use [62]. Globally, 90-95\% strains of S.aureus have attained resistance against Penicillin, while $70-80 \%$ of them are known to be resistant against most potent methicillin antibiotic in Asian countries [63]. Currently, MRSA infections are treated by Vancomycin, Teicoplanin, Linezolid and Daptomycin antibiotics. However, the progression of resistance mechanisms in MRSA against these only available therapeutic drugs is quite distressing. A sporadic rapid emergence of vancomycin-resistant Staphylococcus aureus (VRSA) and vancomycinintermediate Staphylococcus aureus (VISA), and an increase in MIC values of glycopeptides clearly indicate a reduction in MRSA susceptibility to these drugs. Also, the increased resistance and scarceness of any other potent anti-MRSA therapy is observed to further limit the treatment options in near future [47]. A rapid increase in practical utilization of alternative or combinatorial approaches for prevention and cure for MRSA infections must come to the rescue. Owing to this dire need, a brief overview of such antimicrobial alternatives against MRSA infections has been presented with the particular discussion on their relevant research findings and their future prospects. The (Fig. 4) represents an overview of such anti-MRSA alternatives that can exert an antimicrobial effect on MRSA alone or can potentiate the effects of existing antibiotics in combinatorial approaches. 


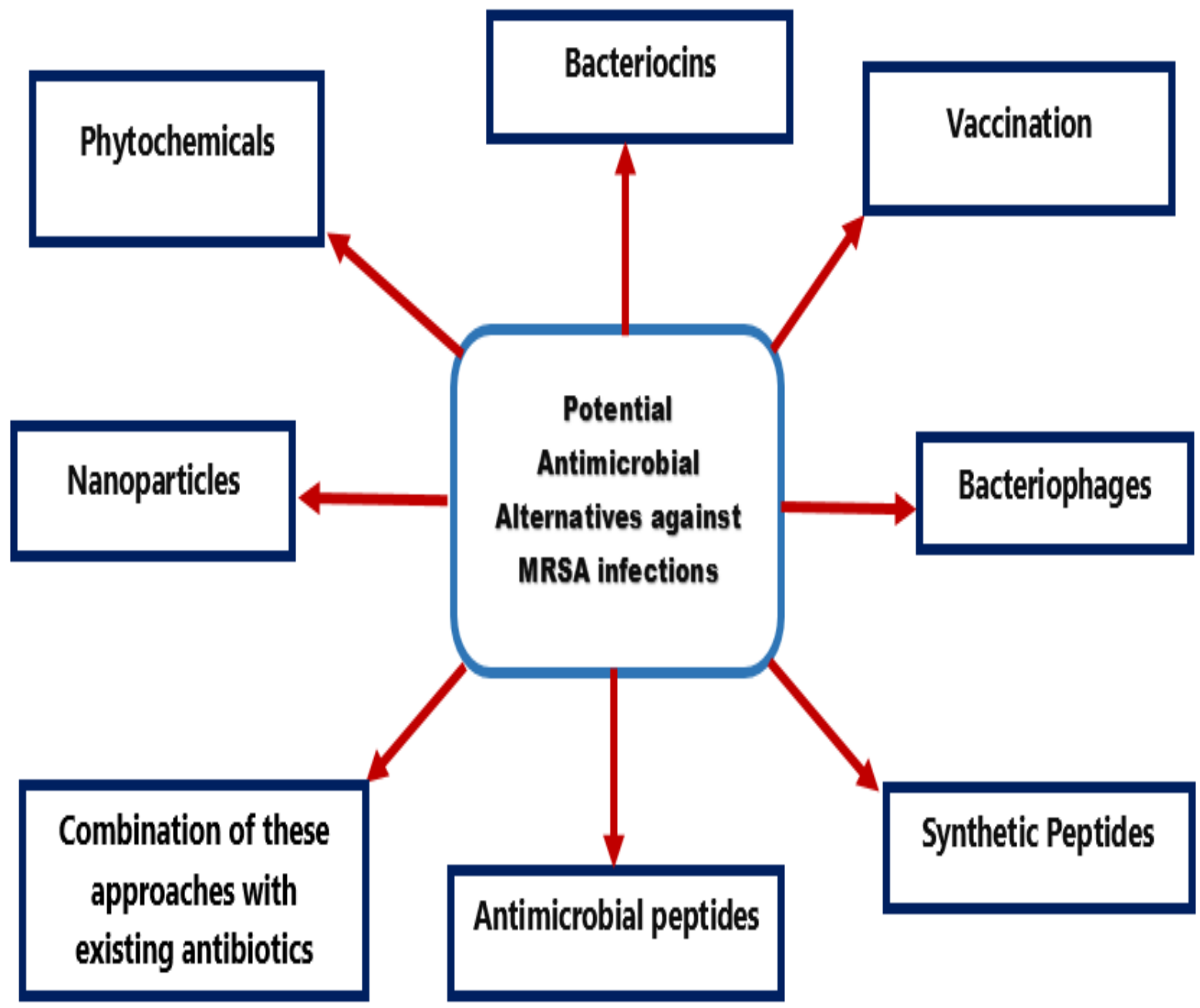

Figure 4. Schematic overview of potential alternative therapies against MRSA infections

\section{Phytochemical approach}

The utilization of various plant regions i.e., leaf, stem, bark and roots, etc. for preventing diseases, relieving the symptoms and regression of abnormalities that arise due to various reasons has a long history [64]. Many communities across the world (about $60 \%$ of the total world's population and $80 \%$ of developing countries) still rely on and consider this traditional herbal-therapeutic approach as the preferable primary solution to their medical issues [65]. Due to the rapid emergence of antibiotic resistance in many clinical isolates all around the globe, the need to find substitute antimicrobial agents has become paramount than in previous years. Owing to this fact, research interest has been invigorated in searching for suitable bioactive anti-microbial compounds from plants.

Plants have been found to act as a natural source of harboring a wide variety of valuable bioactive compounds, that have extra-ordinary potential to combat currently problematic antibiotic resistantbacterial infections. And it is an accepted fact that numerous commercially available modern medicines were successfully used in their crude forms in traditional healing practices too. Plant-derived medicines also offer profound clinical benefits due to their comparatively safer nature than synthetic drugs [66]. The antimicrobial traits of plants are attributed to their phytochemicals synthesized primarily 
during their secondary metabolism. These secondary metabolites are produced as defense mechanisms against microbes, insects, and other predators, while some aid plants in communication with other organisms in their eco-systems [67]. Among these secondary metabolites, tannins, flavonoids, phenolic compounds and alkaloids are the most potent antimicrobial bioactive compounds [68]. Due to the incomparable chemicaldiversity existence in natural extracts and their novel mechanisms of actions, they open new avenues and unlimited opportunities in the development of new drugs against resistant strains [69] It was reported by Wilkins \& Board in 1989 that more than 1340 plants are known that have potential antimicrobial effects [70] while the total number of plant species on Earth is estimated to be about 250,000 to 500,000 species [71].

Different parts of plants (from seeds to roots) have been extensively studied for their anti-infection properties. A number of research findings on different plant extracts and essential oils have been conducted to combat the challenge of MRSA [72]. For a plant-extract, the appropriate Minimal Inhibitory Concentration (MIC) value considered to exhibit anti-MRSA effect is $250 \mathrm{mg} / \mathrm{mL}$ to $1 \mu \mathrm{g} / \mathrm{mL}$. Concentrations of extracts $>1 \mathrm{mg} / \mathrm{mL}$ are not considered inhibitory because bacteriostatic/bactericidal effects can be due to osmotic stress applied by solutes on cell-walls of bacteria [73]. 62.5-250 $\mu \mathrm{g} / \mathrm{mL}$ of Bauhinia kockiana Korth flower-extract showed anti-MRSA potential [74]. Examination of ethanolic extraction of 10 traditional medicinal plants against MRSA activity also showed promising results [75]. Also, a detailed literature review of medicinal plants against MRSA has been presented by Li et al., 2019 and Ramírez Rueda, 2013 [76,77].

\section{Anti-MRSA potential of essential-oils}

The antibiotic activity of many plantsextracts is mainly due to essential-oil fraction or due to Sulphur containing compounds in aqueous phase [78]. Essential oils are complex volatile mixtures of 20-80 components present essentially in plants in very minute concentrations. Their extraction from plants can be done through various methods i.e., via solvent extraction, super-critical $\mathrm{CO} 2$ and subcritical water extraction, steam-distillation hydrodiffusion as well as via solvent-free microwave and combination (solvent + steam) methods [79]. Plants store their essential oils in various cell-compartments that include secretory cells, cavities and glandular trichomes [80]. Chemical composition of essential oil depends upon harvesting period, climatic, seasonal, geographical situations, and upon particular distillation technique used. Other potential properties of essential oil include their diverse chemical compositions, wide antimicrobial spectrum, least toxicity and broad pharmacological activities. Particular kind, composition, concentration, storage condition of essential-oil as well as nature and inoculum size of target bacteria are the influencing factors of their antibacterial activities [81].

Melaleuca alternifolia essential oil is considered the first essential oil that demonstrated anti-MRSA activity [82]. In a research finding, a combination of citricidal and geranium oil exhibited the highest antibacterial potential against MRSA. This finding also showed that essential-oils work best in vapour form and in combinatorial forms than single oils used alone. However, in dressing method, with Flamazine presence, these vapors were failed to obstruct the growth of S.aureus strains, the thick coating of Flamazine might prevented the antibacterial effects of volatile vapors on S.aureus strains [83]. Similarly, in another study the anti-MRSA effects of 10 essential oils were examined, the essential oils of cinnamon and thyme were found to be the most powerful ones against MRSA, $25 \mu \mathrm{l} / \mathrm{ml}$ was the lowest concentration that formed effective $9 \pm 0.085 \mathrm{~mm}$ and $8 \pm 0.051 \mathrm{~mm}$ clear zones of inhibition around MRSA culture. Also, 
increased antibacterial activity of Amoxicillin was observed when used in combination with active components of essential oils of oregano and pennyroyal mint. No effective outcome was obtained when the latter two essential oils were used alone against MRSA [84]. Cold-pressed orange essential oil is also potent antistaphylococcal agent for topical MRSA infections [85] (Table 4) lists some other essential oils that have been studied for their anti-MRSA potential. The combination of essential oils with one another and with antibiotics increase not only the antibacterial activities but also reduced the MIC of antibiotics than if they were used alone [86].

Table 4. Potential essential oils effective against Methicillin-resistant Staphylococcus aureus (MRSA)

\begin{tabular}{|c|c|c|c|c|c|c|}
\hline $\begin{array}{c}\text { Essential } \\
\text { oil }\end{array}$ & $\begin{array}{c}\text { Amount of } \\
\text { Essential oil } \\
\text { used }\end{array}$ & $\begin{array}{c}\text { Diameter of } \\
\text { Zone of } \\
\text { inhibition(mm) }\end{array}$ & MIC $^{1}$ & $\mathrm{MBC}^{2}$ & Mechanism of action & Ref \\
\hline $\begin{array}{c}\text { Lemongras } \\
\text { s oil }\end{array}$ & \multirow{3}{*}{$\begin{array}{c}10 \square \mathrm{L} / 6 \mathrm{~mm} \\
\mathrm{disc}\end{array}$} & $20-29 \mathrm{~mm}$ & \multirow{3}{*}{$\mathrm{NA}^{3}$} & \multirow{3}{*}{ NA } & NA & \multirow{3}{*}{ [87] } \\
\hline $\begin{array}{c}\text { Eucalyptus } \\
\text { oil }\end{array}$ & & $8-14 \mathrm{~mm}$ & & & NA & \\
\hline $\begin{array}{c}\text { Tea Tree } \\
\text { oil }\end{array}$ & & $9-15 \mathrm{~mm}$ & & & $\begin{array}{l}\text { cause degradation of the } \\
\text { bacterial cell wall and } \\
\text { reduction in osmotic } \\
\text { tolerance }\end{array}$ & \\
\hline $\begin{array}{l}\text { Melaleuca } \\
\text { alternifolia } \\
\text { (Tea Tree } \\
\text { oil) }\end{array}$ & NA & NA & $\begin{array}{c}0.50 \\
(\% \mathrm{v} / \mathrm{v} \\
)\end{array}$ & $\begin{array}{c}2 \\
(\% \mathrm{v} / \mathrm{v} \\
)^{2}\end{array}$ & $\begin{array}{l}\text { Eucalyptol found as main } \\
\text { antimicrobial component, } \\
\text { might } \\
\text { contribute in } \\
\text { permeabilization of target- } \\
\text { bacterial membranes and } \\
\text { thus facilitate the entry of } \\
\text { other active components }\end{array}$ & [88] \\
\hline $\begin{array}{l}\text { Eucalyptus } \\
\text { globulus } \\
\text { (Southern } \\
\text { blue gum) }\end{array}$ & $12 \square 1 /$ disc & $8 \mathrm{~mm}$ & $\begin{array}{c}85.6 \\
\mu \mathrm{g} / \mathrm{mL}\end{array}$ & NA & $\begin{array}{l}\text { Eucalyptol }(47.2 \%) \text { was } \\
\text { found as the main } \\
\text { component of essential oil. }\end{array}$ & \\
\hline $\begin{array}{l}\text { Thymus } \\
\text { vulgaris } \\
\text { (thyme) }\end{array}$ & $12 \square 1 /$ disc & $12 \mathrm{~mm}$ & $\begin{array}{l}18.50 \\
\mu \mathrm{g} / \mathrm{ml}\end{array}$ & NA & $\begin{array}{l}\text { Thymol }(48.1 \%) \text { was found } \\
\text { the active compound of } \\
\text { essential oil. It inhibits } \\
\text { synthesis of biofilm } \\
\text { components i.e., } \\
\text { polysaccharide intercellular } \\
\text { adhesin (PIA) and } \\
\text { extracellular DNA (eDNA). }\end{array}$ & $\begin{array}{l}{[89,} \\
94]\end{array}$ \\
\hline \multirow[t]{2}{*}{ T.schimper } & $10 \square \square 1 /$ disc & $16 \pm 0.4 \mathrm{~mm}$ & \multirow{2}{*}{$\begin{array}{c}3.12 \\
\mu \mathrm{l} / \mathrm{ml}\end{array}$} & \multirow{2}{*}{$\begin{array}{c}6.25 \\
\mu \mathrm{l} / \mathrm{ml}\end{array}$} & \multirow{6}{*}{$\begin{array}{l}\text { Essential oils when used in } \\
\text { combination produced } \\
\text { strong inhibitory effects and } \\
\text { involvement of many } \\
\text { antimicrobial mechanisms } \\
\text { produced this synergism }\end{array}$} & \multirow{6}{*}{ [90] } \\
\hline & $20 \square \square 1 /$ disc & $21 \pm 0.3$ & & & & \\
\hline \multirow{2}{*}{$\begin{array}{c}\text { B. } \\
\text { cuspidate }\end{array}$} & $10 \square \square \mathrm{l} / \mathrm{disc}$ & $19 \pm 0.2$ & \multirow[t]{2}{*}{$\begin{array}{c}1.56 \mu \\
1 / \mathrm{ml}\end{array}$} & \multirow[t]{2}{*}{$\begin{array}{l}3.12 \\
\mu 1 / \mathrm{ml}\end{array}$} & & \\
\hline & $20 \square \square 1 /$ disc & $25 \pm 0.1$ & & & & \\
\hline \multirow[t]{2}{*}{$\begin{array}{c}B . \\
\text { ogadensis }\end{array}$} & $10 \square \square 1 /$ disc & $12 \pm 0.1$ & \multirow{2}{*}{$\begin{array}{c}3.12 \mu \\
1 / \mathrm{ml}\end{array}$} & \multirow{2}{*}{$\begin{array}{l}6.25 \\
\mu 1 / \mathrm{ml}\end{array}$} & & \\
\hline & $20 \square \square 1 /$ disc & $17 \pm 0.3$ & & & & \\
\hline
\end{tabular}

${ }^{1}$ : Minimum Inhibitory Concentration; ${ }^{2}$ : Minimum Bactericidal Concentration; ${ }^{3}:$ Not available 
The antibacterial activities of plant-extracts and essential oils can be due to number of bioactive compounds present in different fractions of the extracts. Each antimicrobial phytochemical exerts a different and unique mechanism of action the details of few are given in (Table 5). Carvacrol is one such widely existing phytochemical that belongs to phenolic and polyphenolic class of secondary metabolites and has a hydrophobic nature. The hydroxyl group on its aromatic ring plays crucial role in its antiinfective property. $\mathrm{H}$-bonding is involved in its interaction with Target bacterial DNA. Antibacterial potential of Carvacrol can be enhanced by low $\mathrm{pH}$ adjustments because reduced $\mathrm{pH}$ plays role in minimizing the dissociation of carvacrol and thereby augment its hydrophobicity, this increases the likelihood of carvacrol strong binding with hydrophobic regions of membrane's protein, and therefore better penetration of carvacrol can occur in membrane lipids and antibacterial effect is increased [91]. Another important phenolic structure having essential component is Eugenol which due to its $\mathrm{OH}$ group exerts its antibacterial effects [92].

Similarly, Thymol a monoterpene phenol, mostly present in oregano essential oil is also potent against MRSA infections. At values lower than MIC, thymol also prevents biofilm formation by MRSA [93]. In a recent research finding it is found that thymol cannot only prevent the formation but also the elimination of pre-formed mature MRSA biofilms by reducing the synthesis of polysaccharide intracellular adhesin (PIA) with concomitant release of extracellular DNA from MRSA cells. Also synergistic treatment of thymol and vancomycin was found more remarkable than vancomycin monotheraphy in mouse infection model for removal of MRSA biofilms [94]. Sesquiterpenes, a class of terpenoids are well established to potentiate the action of antibacterial action antibiotics against $S$. aureus strains [95].

Flavones are other ubiquitously present structures in plant-extracts, they exhibit phenol like structures with at least one carbonyl group. The addition of 3-hydroxyl group to this basic structure yields flavonol [96]. 3.13-6.25 $\mu \mathrm{g} / \mathrm{ml}$ concentrations of tetra-hydroxyflavanones isolated from Sophora exigua and Echinosophora koreensiare are strong enough to inhibit the growth of clinically isolated MRSA strains [97]. Catechin,the strong antimicrobial compounds are also the reduced forms of flavonoids [98]. Catechins alone don't have exceptional innate potential to inhibit MRSA growth but can enhance the susceptibility of MRSA to $\beta$-lactam antibiotics in combinatorial approaches [99]. Substitution of catechin with other components is also useful strategy because 3-O-octanoyl catechin was found to be bactericidal against MRSA due to its increased membrane damaging potential as compared to Epicatechin gallate when used alone without any substitution with 3-O-acyl chains of variable lengths (C4C18) [100]. Tannins are also found useful in inhibiting growth of clinically isolated and reference strain of MRS (AATCC 43300) [101]. A schematic illustration of the general antimicrobial mechanism of action of an essential oil on MRSA cell is shown in (Fig. $5)$. 


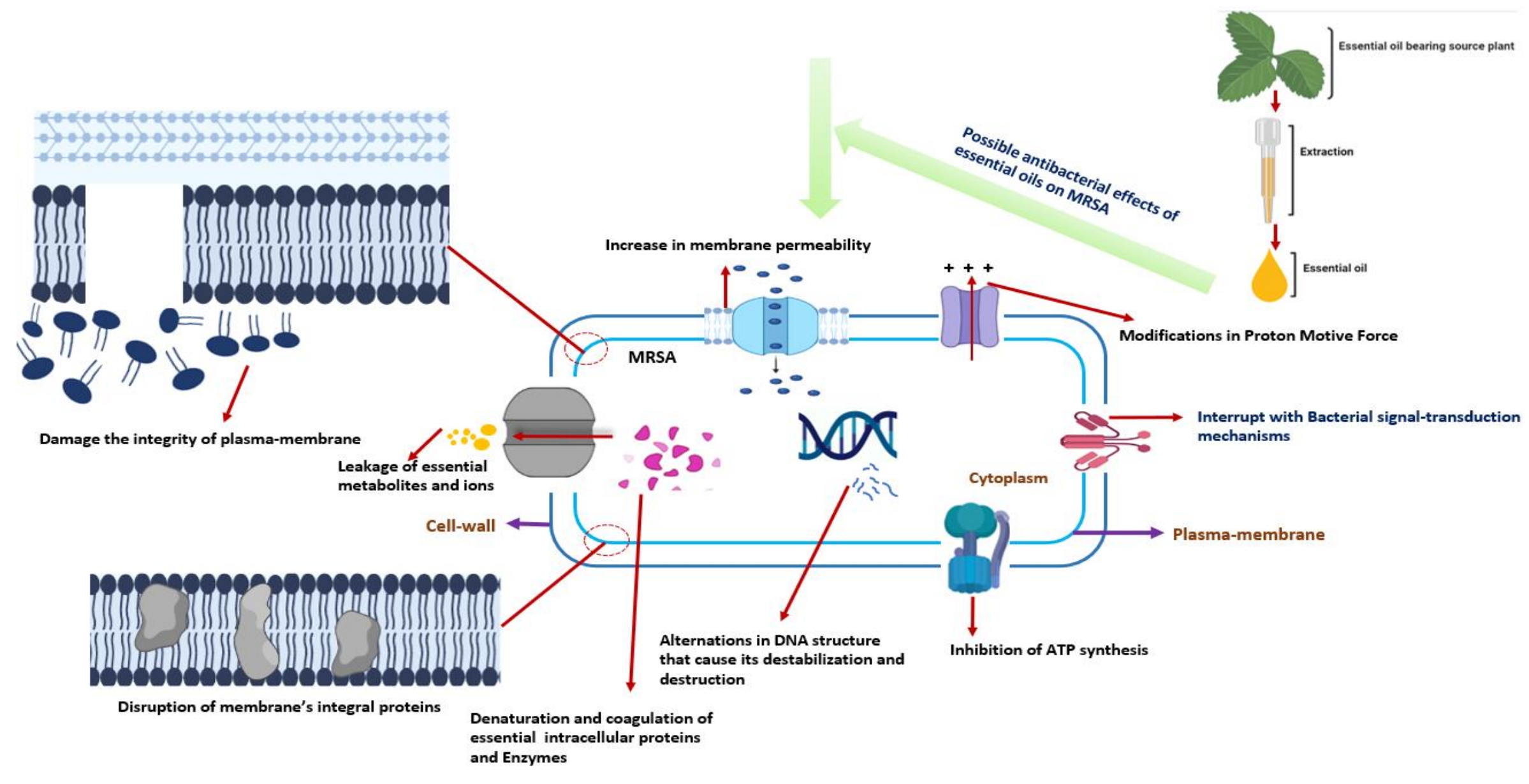

Figure 5. General Mechanism of anti-bacterial action of essential oils on MRSA 
Table 5. Mechanism of action of some potent phytochemicals against MRSA

\begin{tabular}{|c|c|c|}
\hline $\begin{array}{l}\text { Potent bioactive } \\
\text { phytochemicals }\end{array}$ & Mechanism of action & Ref. \\
\hline Carvacrol & $\begin{array}{l}\text { - interacts with bacterial-plasma membrane to cause } \\
\text { destabilization and expansion of membrane's structure thus } \\
\text { fluidity and permeability of membrane is disturbed. } \\
\text { - Has ability binding with minor groove of S.aureus DNA }\end{array}$ & [91] \\
\hline Eugenol & - Involved in Enzyme inhibition of target bacterium & [92] \\
\hline Thymol & $\begin{array}{l}\text { - } \\
\text { - Ilters plasma-membrane permeability } \\
\text { - } \quad \text { prevents biofilm formation }\end{array}$ & [93] \\
\hline Terpenoids & $\begin{array}{l}\text { - involved in inhibition of two crucial microbial processes: } \\
\text { oxidative phosphorylation and oxygen uptake. }\end{array}$ & {$[102]$} \\
\hline $\begin{array}{c}\text { Clerodane } \\
\text { diterpene (CD) }\end{array}$ & $\begin{array}{l}\text { - involved in modulating the expression of efflux pump genes of } \\
\text { MRSA } \\
\text { also extends post-antibiotic effect in synergy or non-synergy } \\
\text { with norfloxacin }\end{array}$ & [103] \\
\hline Flavonol & $\begin{array}{l}\text { - form complexes with target-bacterial-cell walls and other } \\
\text { extracellular/soluble proteins. } \\
\text { highly hydrophobic flavonoids are also associated with damage } \\
\text { to microbial membranes }\end{array}$ & [96] \\
\hline Catechin & $\begin{array}{l}\text { - Catechin gallate can intercalate into phospholipid bilayers of } \\
\text { target bacteria thereby, can alter the virulence and antibiotic } \\
\text { resistance patterns in bacterial strain } \\
\text { in combinatorial approaches can enhance the susceptibility of } \\
\text { MRSA to } \beta \text {-lactam antibiotics. }\end{array}$ & $\begin{array}{l}{[98],} \\
{[99]}\end{array}$ \\
\hline Tannins & $\begin{array}{l}\text { - } \quad \text { induce cell-wall disruption } \\
\text { - } \quad \text { involved in release of intracellular-cytoplasmic constituents } \\
\text { - Suppress essential ribosomal pathways involved in transcription, } \\
\text { protein-synthesis and DNA modification and repair processes. }\end{array}$ & [101] \\
\hline Alkaloids & $\begin{array}{l}\text { - Involved in pyruvate kinase inhibition } \\
\text { - } \quad \text { modulation of efflux pumps } \\
\text { - intercalation with bacterial DNA } \\
\text { - inhibition of Quorum sensing-effects biofilm prevention. }\end{array}$ & [104] \\
\hline
\end{tabular}

Despite having such strong antimicrobial potential, certain limitations impede practical utilization of essential oils in being acting as a major ingredient in any new therapeutic drug against MDR infections. Their isolation from plant organs is extremely laborious and energy intensive, their testing as potential antimicrobial agent requires their safe extraction and complete purification. Ascertaining their bioactive component being responsible for making them antimicrobial candidates is also a difficult task after initial anti-infective screening tests. Also, in comparison with synthetic additives, they pose high-cost concerns due to their additional processing requirement prior to their testing of antimicrobial activity. Cost issues can be resolved by downsizing the total extraction volume of potential antimicrobial components [105]. However, the other major problem associated with anti-MRSA plants is their safety concerns, because some secondary metabolites of medicinal plants have also shown strong carcinogenic, mutagenic and toxic potential [106-108]. To address this issue, a critical evaluation and sequential screening of their antimicrobial, pharmacological, and toxicological aspects is required for ascertaining their safety 
profile on immediate basis before their approval by regulatory authorities.

\section{Bacteriocins and antimicrobial peptides}

Bacteriocins are ribosomally synthesized small bacterial peptides that have Bacteriostatic and bactericidal potential against competing bacterial strains [109]. They are most valuable alternatives of conventional therapeutic antibiotics against clinical pathogens due to their high stability, non-toxicity, high potency even at very low concentrations, and due to their broad and spectrum of activity against competing strains [110]. It is investigated that bacteriocins are naturally produced in our GIT by certain species of lactic acid bacteria against infectious pathogens that gain entry through food. They are also emerging as potent anti-cancer, antifungal and antiviral substances. Bacteriocins from LAB (lactic acid bacteria) have attained GRAS status from FDA and Nisin is the only FDA approved commercially available bacteriocin used as food preservative in western countries [109]. Nisin exerts its strong antimicrobial effect by formation of pores in cell-membranes and subsequent efflux of essential metabolites from target cell [111]. The (Fig. 6) depicts the mechanism in which nisin is produced by producer bacteria. The genes involved in Nisin biosynthesis are present on $70 \mathrm{k} . \mathrm{b}$ conjugative transposon The NisK senses the existence of nisin in the external environment and auto-phosphorylates. The $\mathrm{Pi}$ is transferred to Response regulator gene (NisR), which triggers transcription of the nisABTCIP genes that encode structural, modification, transportation, Immunity and maturation proteins; NisFEG.along with NisI confer Immunity and defend the producer-cell from toxicity of nisin (where P: promoter region, \& $\mathrm{P}$ ',P" represent nisin-regulated promoters in operon cluster) [112]. The released Nisin then acts on target bacterial strains and inhibit their growth.

Activity of bacteriocins against MRSA has been tested by various researches with fruitful results $[110,113,114]$ In finding by Karska-Wysocket al., 2010, 99\% elimination of the MRSA cells was obtained on direct interaction with LAB after 24 hours at $37^{\circ} \mathrm{C}$ incubation [115]. Due to their strain specific inhibitory activities Aureocin A53 and epidermin from Staph. aureus and Staph. epidermidis respectively also shown potential effects against MRSA [116].

Also, another effective strategy would be utilization of antimicrobial peptides (Host defense peptides) that are small cationic peptides and have ability to combat infections either by directly killing the pathogens or by modulating host's defense responses. They are present in almost all life forms against infectious agents [117]. Electrostatic interactions between positively charged AMPs and negatively charged bacterial surface are leading the factors of their antimicrobial activities, they can either physically disrupt the integrity of host's plasma-membrane or can translocate the membrane for interacting with intracellular targets [118]. Hydrophobic nature of these peptides allows penetration through anionic lipid membrane. These compounds have gained importance and are being used against antibiotic resistance [119]. Omiganan Pentahydrochloride (MBI 226 ) is 12 amino-acid cationic peptide was found effective against MRSA at MIC of $\leq 64 \mathrm{mg} / \mathrm{ml}$ [120]. Similarly, another peptide Chitosan in its aminoderivatizied form showed promising results in synergy with $\square$-lactams against MRSA strains with Fractional inhibitory concentration (FIC) indices of $0.252-0.508$ with a significant reduction in MIC of $\square \square$ lactams [121]. Another peptide L12 derived from enterocin, of E. faecium was also found effective against MRSA infections [122]. Despite their strong anti-MRSA potential, for both, AMP's and Bacteriocins, thorough insights are required to answer questions related to their poor solubility and stability, high production and purification costs. Their inactivity by degradation of intestinal proteases also makes them less effective in-vivo [111]. 
Low in-vivo metabolic stability due to tissue-proteases also limits clinical use of AMP's. A deep understanding of both AMP's and bacteriocin's biology and biochemistry is required for formulation of innovative approaches and drug-delivery systems for improving the aspects of safety, stability, and antimicrobial-effectiveness at low concentrations.

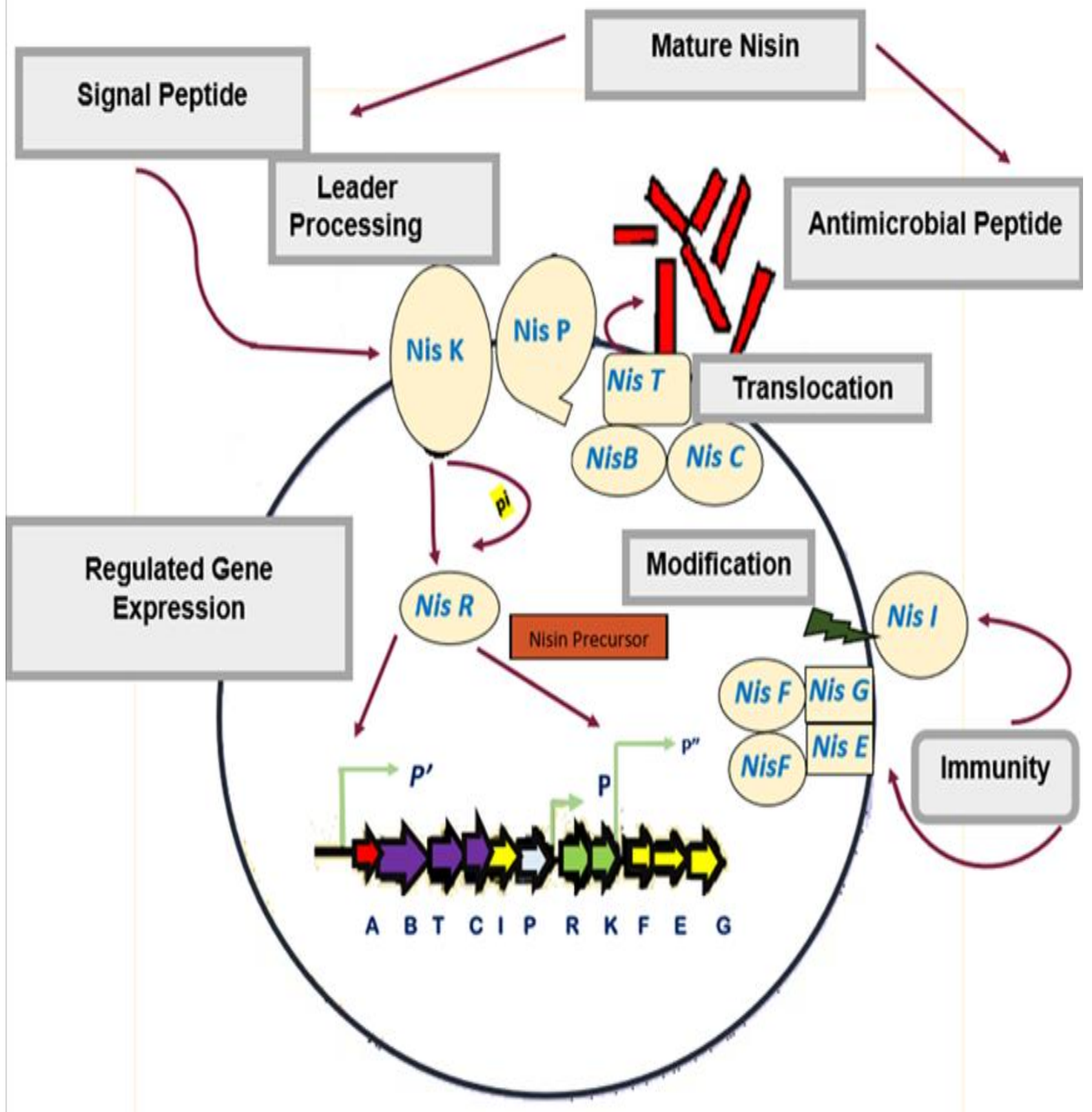

Figure 6. Presumed Model of Labtibiotic Nisin Biosynthesis [112] 


\section{Phage therapy}

To combat against the global threat of antibiotic resistant strains particularly MRSA, another effective strategy is utilization of bacteriophages. These bacterium eating viruses have huge therapeutic potential because bacteriophages can only interact with and kill their specific bacterial hosts. In Lysogenic states they incorporate their genomic DNA into bacterial genome and exist as prophage and through multiple crucial mechanisms prophage controls bacterial-pathogenicity and behavior $[123,124]$. Lytic phages have high potential to disrupt host's metabolism thus cause rapid lysis of target bacterial cells. They are highly specific towards their target bacterial species or even strains [125]. Felix d'Herelle, is known as the first microbiologist who observed bacteriophage phenomenon in 1910 in Mexico [126]. In 1917 he started administration of phages in different patients via ingestion phenomenon and found them efficacious against different bacterial diseases [127]. Since then, numerous researches have been conducted against their anti-infective potential for known resistant and susceptible bacterialstrains. Bacteriophages are far better than antibiotic strategy of controlling infectious diseases because they do not induce secondary infections produced as a result of antibiotic-associated dysbiosis of normal flora, directly concentrate and replicate at the site of infection for immediate lysing of pathogenic bacteria instead of distributing throughout the body like antibiotics. They are not known to cause any side effects during or after their administration while antibiotics can pose concerns of allergies, secondary infections and resistance in pathogenic bacteria. Also, if under some circumstances, target bacteria attain resistance against phage, it will remain susceptible to other phages having identical target-range [128]. Additional benefits of bacteriophages over other antimicrobial agents include their auto-replication ability and eco-friendly status [123]. They are also more effective in terms of costeffectiveness over antibiotics. However, their combination with antibiotic may prove a valuable approach for therapeutics of infectious diseases [129]. Owing to these facts and rapid emergence of MRSA strains worldwide, bacteriophage effectiveness has also been evaluated against MRSA strains from different sources and promising results have been procured. The (Table 6) represents some promising studies to control MRSA infections via bacteriophage therapy.

Irrespective of the fact that large number of publications are present about phage therapy but very limited ones are known to reveal the pharmacokinetics and toxicology of therapeutic phages, the detailed and critical information is required for their successful implementation in clinical settings. Findings of some researchers suggest that bacteriophages can get entry into bloodstream of laboratory animals within 2-4 hours and their persistence within internal organs can be found within 10 hours of administration. They can sustain within in human bodies for relatively extensive period i.e., till up to several days [127].

Other technical and financial issues regarding their production at large scale involves serious attention because they need to be produced within their bacterial hosts, and pathogenic bacterial hosts involvement requires high safety protocols for working members in the production plant and nearby community. Another important challenge is implementation of maximum precautionary measures (for not producing a virulent and pathogenic gene transferring phage) while propagating therapeutic phages within their host bacteria, because some phages can carry host's pathogenicity inducing genes to other previously non-virulent bacteria. Although chances of such events to occur are very rare but cannot be overlooked. Alternative strategy for coping up with the issue is generation of avirulent, non- 
pathogenic and genetically wellcharacterized producer bacteria, but again preparation of such bacterial hosts is highly cost-intensive and requires prolonged periods of investigation and throughput [134]. MRSA associated skin and mucous membrane infections might not require application of whole therapeutic phage rather administration of its active lytic enzyme that induces host's cell-lysis is sufficient. A pictorial representation of bacteriophage's mode of action on host bacterial cell by lytic cell-cycle and by its endolysin (lytic enzyme) is shown (Fig. 7). Viability of this approach is proved by experimental findings of Loeffler et al., 2001 who observed rapid killing of Streptococcus pneumoniae via pneumococcal bacteriophage lytic enzyme (Pal) that was basically a cell-wall hydrolase [135].

\section{Nanoparticles}

Besides being used in delivering antiMRSA agents, nanoparticles can themselves be used against MRSA strains. For this, various materials have been investigated to design nanoparticles against MRSA. As like the naturally occurring peptides that can cross the lipid membrane and meld into the target species thereby disrupting the structure of the membrane, the cationic nanoparticles exhibit antimicrobial activity due to similar attributes. This mechanism of interaction between positively charged nanoparticle and negatively charged bacteria has been shown in (Fig. 8) where the high charge density on the nanoparticle might be due to amines or alkylated ammonium groups that protrude from the outer-surface and develops interaction with the negatively charged bacterial membrane [136].

The antimicrobial properties of chitosan (that is both biodegradable and biocompatible) nanoparticles have also been investigated. They exhibit quaternary ammonium groups on their surfaces and formed by ionic gelation. Through assays, it is revealed they are active against MRSA biofilms. This ability is due to the cationic charges on the external surface of nanoparticles which develop interaction with the negatively charged bacterial cell surface, thereby weakening the membrane [137]. Similarly, nanoparticles with metallic nature have also been examined with silver being the most studied one [137]. This is because it can be taken up by the bacterial species and cross their cell-walls [138]. In addition to this, silver ions can interact with the thiol group present on cysteine amino-acid [139]. As Ag ions exhibit strong affinity for Phosphorous ions present in the DNA, they can affect DNA replication [138]. The size of the Ag+ nanoparticle effects the anti-MRSA activity and cytotoxicity toward the human cells. A small size of $10 \mathrm{~nm}$ is very active with no cytotoxicity whereas $100 \mathrm{~nm}$ is lethal for both bacteria and eukaryotes. Silver nanoparticles are less toxic compared with ionic silver against eukaryotic cells. Highly charged silver ion e.g. Ag (+3) contains stronger antibacterial properties compared with Ag (+1) [140].

Copper-oxide nanoparticles, on the other hand, are required at higher concentrations to kill bacteria. The mechanism of action is different from silver nanoparticles, as the release of copper-ions leads to a change in $\mathrm{pH}$ and charge which disrupts the membrane and affects the function of intracellular molecules like enzymes. Zinc oxide nanoparticles cause cell lysis by damaging the membrane lipids and proteins. Different metallic nano-particles can be used as surface coating materials for medical devices. Copper nano-particles provide anti-MRSA coating as well [137]. However, the size of nanoparticle can also pose toxicity concerns as compared to micrometer particle of the same size [141]. The need of the hour is to know the interaction of MeO-NPs with human-cells and organs, such as their ability to cross the blood-brain barrier and the blood-testicular barrier [142]. Also, MeO-NPs interaction with $\mathrm{ABC}$ transporters can also bring new insight into their mechanism of action [143]. 
Table 6. Some novel bacteriophages against MRSA infections

\begin{tabular}{|c|c|c|c|}
\hline $\begin{array}{l}\text { Bacteriophage } \\
\text { Collection-site }\end{array}$ & Findings & Results & Ref. \\
\hline Hospital sewage & $\begin{array}{c}\text { Bacteriophage-titer: } 1 \times 10^{\wedge} 9 \\
\text { PFU/ml } \\
\text { latent period: } 20 \mathrm{~min} \\
\text { Burst size: } 190 \\
\text { PFU/infected cell }\end{array}$ & $\begin{array}{l}\text { The isolated phage was } \\
\text { effective against } 27 \text { out of } \\
30 \text { MRSA strains isolated } \\
\text { from hospitalized burnt } \\
\text { patients }\end{array}$ & {$[130]$} \\
\hline $\begin{array}{c}\mathrm{f} \\
\text { LizAnk Bacteriopha } \\
\text { ge isolated from } \\
\text { clinically isolated } \\
\text { MRSA strains } \\
\text { during performance } \\
\text { of infectivity studies } \\
\text { on } 13 \text { lysogenic } \\
\text { phages against } \\
\text { MRSA strains }\end{array}$ & $\begin{array}{c}\text { Time taken by phage to kill } \\
10^{\wedge} 7 \mathrm{CFU} / \mathrm{ml} \text { of MRSA: } 8 \\
\text { hours }\end{array}$ & $\begin{array}{l}\text { The isolated phage was } \\
\text { potent antibacterial agent } \\
\text { against } 6 \text { clinically isolated } \\
\text { strains of MRSA and } \\
\text { exhibited no cytotoxicity } \\
\text { against mammalian cell }\end{array}$ & {$[131]$} \\
\hline $\begin{array}{c}10 \text { lytic } \\
\text { bacteriophages were } \\
\text { collected from raw } \\
\text { sewage water }\end{array}$ & $\begin{array}{c}\text { Only } 2 \text { bacteriophages } \\
\Phi \text { NUSA- } 1 \text { and } \Phi \text { NUSA-10 } \\
\text { showed remarkably broad } \\
\text { host-range against }>80 \% \text { of } \\
\text { MRSA and MSSA tested. }\end{array}$ & $\begin{array}{l}\text { Wide host range of isolated } \\
\text { bacteriophages including } \\
\text { both MSSA and MRSA } \\
\text { supports hypothesis that } \\
\text { bacteriophages employ } \\
\text { inhibitory mechanisms } \\
\text { clearly distinct from } \\
\text { bactericidal mechanism of } \\
\text { antibiotics. Also sewage } \\
\text { water is a valuable source } \\
\text { for clinically potent } \\
\text { staphyphages }\end{array}$ & {$[132]$} \\
\hline $\begin{array}{l}\text { Sewage sample of } \\
\text { Ruijin Hospital }\end{array}$ & $\begin{array}{c}\text { burst size: } 13 \text { PFU/ml } \\
\text { infected cell } \\
\text { Phage's stability } \\
\text { temperature: } 40^{\circ} \mathrm{C} \\
\text { pH: between } \\
\text { 6and } 9 \\
\text { 80\% adsorption on MRSA } \\
\text { surface occurred: in } 4 \\
\text { mins } \\
\text { Latent period: } 12 \mathrm{~min} \\
\text { Growth period: } 9 \mathrm{~min}\end{array}$ & $\begin{array}{c}\text { phage VB_SauS_SH-St } \\
15644 \text { lysed } 12 \text { clinically } \\
\text { isolated MRSA strains out } \\
\text { of } 37 \text { isolates invitro and } \\
\text { subcutaneous injection into } \\
\text { MRSA infected mice } \\
\text { showed its potential against } \\
\text { MRSA skin infections }\end{array}$ & {$[133]$} \\
\hline
\end{tabular}


Faheem et al.

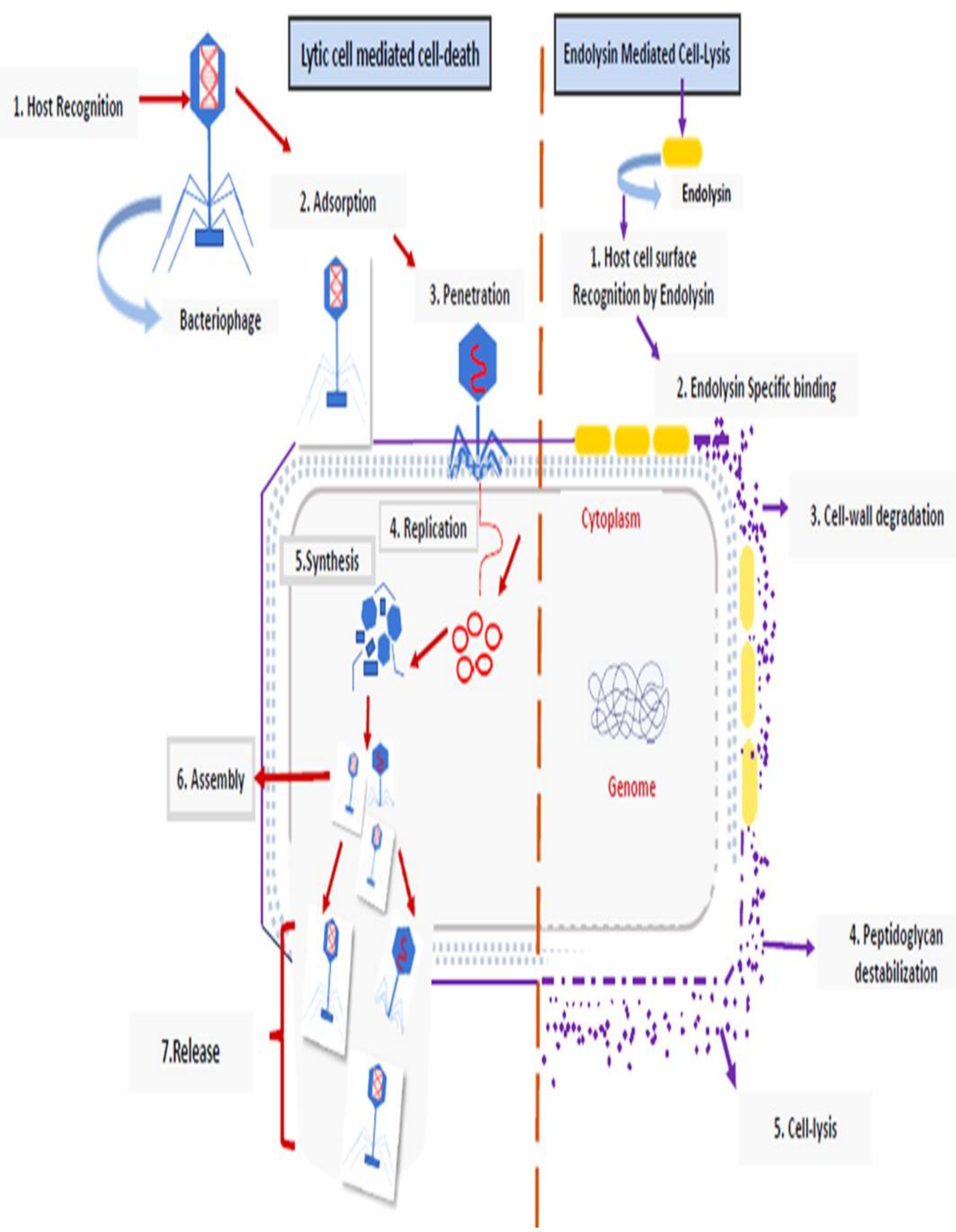

Figure 7. Mechanism of Lytic cell-cycle and Endolysins mediated cell-lysis of MRSA by Bacteriophage 


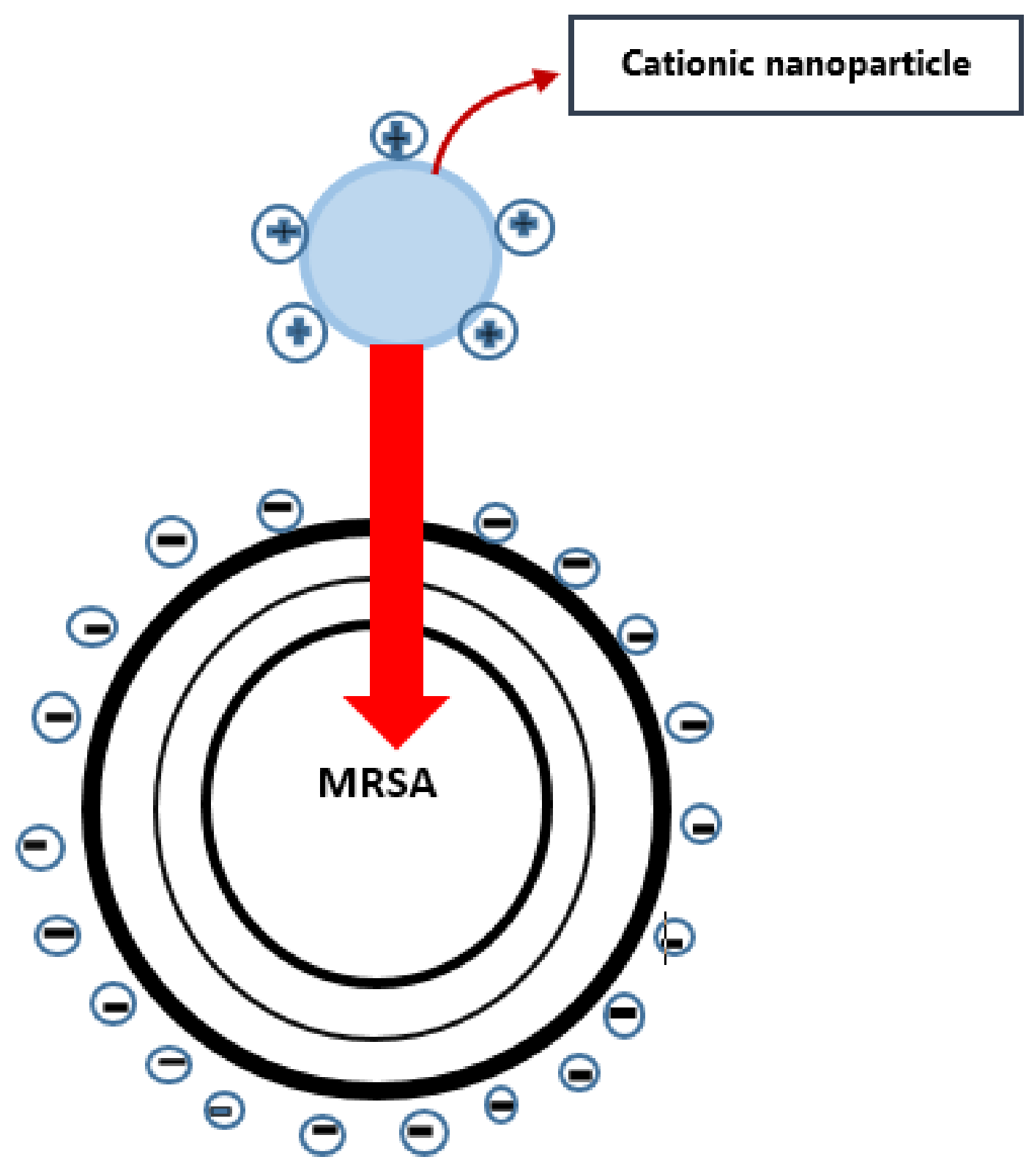

Figure 8. Pictorial representation of positively charged nanoparticle interaction with negatively charged MRSA cell [137]

\section{Other alternative strategies}

Graphene-oxide (GO), is an excellent antibacterial agent, due to its membrane penetrating ability. Also, due to its large surface-area and ultra-high drug loading capability, it is being seen as a potential candidate to be used in conjugation with another strong antibacterial compound, curcumin, against MRSA infections.
Curcumin alone is effective at $125-150 \mu \mathrm{g} / \mathrm{ml}$ concentration, which is inopportunely highly lethal for eukaryotic cells. And Grapheneoxide (GO) although found effective against MRSA infections (at MIC $>60 \mu \mathrm{g} / \mathrm{ml}$ ) needs improvement in its biocompatibility, stability and toxicity concerns. This issue is resolved by a composite based on Curcumin-loaded graphene sheets (GOCU) which has recently 
been found as an effective strategy against MRSA infections even at MIC of $1 \mu \mathrm{g} / \mathrm{ml}$ with a significant reduction in cytoxicity associated with GO [144]. Another potential strategy is the utilization of a pre-emptive approach i.e., vaccination against S.aureus strains, immnotherapeutics have gained renewed interest in the recent years in both human and veterinary medicines [145]. Against PBP2a protein of MRSA, researches have formulated a DNA vaccine that contains $m e c A$ region and antibodies were found to be produced against the specific portion of PBP2a protein that confers resistance to whole MRSA, this vaccination was unaffected on normal microflora but significantly reduced bacterial number in kidneys of infected mice [146]. But due to certain limitations not even a single vaccine against S.aureus (that showed promising results in murine models) has made its way in successful prevention against MRSA in human trials. Due to multiple virulence factors possessed by S.aureus, a vaccine against any one of them might not give significant results in clinical trials so, current trials are particularly focusing on the use of a purified mixture of multiple antigenic preparations. However, utilization of live attenuated D-alanine auxotroph strain of $S$. aureus provides significantly promising results [147].

Lipidated $\alpha /$ Sulfono- $\alpha$-AA heterogeneous peptides have been discovered as a new class of lipid containing peptides. These lipidated and sulphonated peptides mimic host Defense Peptides (HDPs). They are effective against Gram-positive bacteria and the development of resistance in target bacterium is very difficult due to their unique mechanism of action. Moreover, they have been found to be less toxic for humans. Their lipidation, hydrophobicity, and cationic nature are crucial factors in the induction of membrane disruption in target bacteria [148]. However, concerned drawbacks with these synthetic peptides and others include their high cost, stability, and time of synthesis [149].

\section{Strategies for the prevention of transmission}

All medical care staff taking care of MRSA infected or colonized individuals should utilize contact safety measures to restrict spread between patients [150]. This implies putting the MRSA infected patient into a solitary or private room and wearing outfits and gloves when entering the patient's room and eliminating them prior to leaving [150]. Strict contact precautions should be taken throughout an infected person's admission to the hospital and with any person who has recovered from MRSA infection [150]. The hospital should have a management system that can alert the healthcare staff about the readmission or transfer of MRSA-infected patients so that appropriate measures can be taken on the arrival of such patients [150]. Hand hygiene campaigns in hospitals have greatly reduced MRSA infections [151].

Since MRSA can contaminate the air, the rooms of MRSA patients need to be sterilized and disinfect properly. All the furniture including overbed tables, floors, sinks, handrails, and healthcare equipment should be properly disinfected [150]. Decontamination with radiations using Xenon-UV light can also be done and the presence of MRSA and other pathogens can be eliminated up to $99 \%$ [152]. In the design of the building of a healthcare facility, there should be the use of copper alloys to reduce the environmental burden and transmission of pathogens [153]. Intensive care units with a high number of MRSA patients should have an active surveillance program to spot asymptomatic carriers of MRSA [150].

Surveillance along with the prophylactic treatment approach is an effective way to decrease the cases of surgical site infections. These protocols may include intranasal antibiotics such as mupirocin with an antibacterial body wash or preoperative antibiotics. Surveillance is the key, however, to forestall abuse and misuse of antibiotics [154]. 


\section{Conclusion}

Staphylococcus aureus is the cause of multiple types of infections and, unfortunately, Staphylococcus aureus has attained the ability to develop resistance against many drugs and it is known as methicillin-resistant $S$. aureus (MRSA). MRSA has remarkably evolved and disseminated widely in 60 years since it was first identified.

Its huge prevalence in hospital settings poses a huge risk for susceptible individuals in getting nosocomial infections. Increasing drug resistance ability is making them more aggressive and difficult to assassinate by existing antimicrobial approaches (e.g. antibiotics). So MRSA, being the high priority multi-drug-resistant bacteria, requires intensive efforts for research and development of novel preventive approaches, novel genomic driven approaches for drug development must also be explored. Along with that there is the necessity to adapt fast molecular and immunochromatographic diagnostic techniques that can reduce delays in diagnosis and treatment. These factors alone cannot contribute in mitigation of MRSA associated challenges rather, the need for vigilance and effective preventive measures must also be implemented to facilitate the control of this highly successful pathogen.

\section{Authors' contributions}

Conceived and designed the experiments: SM Faheem \& S Riaz, Performed the experiments: SM Faheem \& S Riaz, Analyzed the data: UF Gohar, contributed materials/ analysis/ tools: UF Gohar, Wrote the paper: SM Faheem \& S Riaz.

\section{References}

1. Greenwood D \& O'Grady F (1972). Scanning electron microscopy of Staphylococcus aureus exposed to some common anti-staphylococcal agents. $J$ Gen Microbiol 70: 263-270.

2. Archer GL (1998). Staphylococcus aureus: a well-armed pathogen. Clin Infect Dis 26: 1179-1181.

3. Gordon RJ \& Lowy FD (2008). Pathogenesis of methicillin-resistant
Staphylococcus aureus infection. Clin Infect Dis 46: 350-359.

4. Fuda C, Suvorov M, Vakulenko SB \& Mobashery S (2004). The basis for resistance to $\beta$-lactam antibiotics by penicillin-binding protein $2 \mathrm{a}$ of methicillin-resistant Staphylococcus aureus. J Biol Chem 279: 40802-40806.

5. Hageman JC, Patel J, Franklin P, Miscavish K, McDougal L, Lonsway D \& Khan FN (2008). Occurrence of a USA300 vancomycin- intermediate Staphylococcus aureus. Diagn Microbiol Infect Dis 62: 440-442.

6. van Hal SJ, Jensen SO, Vaska VL, Espedido BA, Paterson DL \& Gosbell IB (2012). Predictors of mortality in $S$. aureus Bacteremia. Clin Microbiol Rev 25: 362-86.

7. Keynan Y \& Rubinstein E (2013). Staphylococcus aureus bacteremia, risk factors, complications, and management. Crit Care Clin 29: 547-62.

8. Liu C, Bayer A, Cosgrove SE, Daum RS, Fridkin SK \& Gorwitz RJ (2011). Clinical practice guidelines by the Infectious Diseases Society of America for the treatment of methicillin-resistant Staphylococcus aureus infections in adults and children: executive summary. Clin Infect Dis 52: 285-92.

9. Han JH, Edelstein PH \& Lautenbach E (2012). Reduced vancomycin susceptibility and staphylococcal cassette chromosome mec (SCCmec) type distribution in methicillin-resistant Staphylococcus aureus bacteraemia. J Antimicrob Chemother 67: 2346-9.

10. Kullar R, Casapao AM, Davis SL, Levine DP, Zhao JJ \& Crank CW (2013). A multicentre evaluation of the effectiveness and safety of high-dose daptomycin for the treatment of infective endocarditis. $J$ Antimicrob Chemother 68: 2921-6.

11. Sakoulas G, Alder J, Thauvin-Eliopoulos C, Moellering Jr RC \& Eliopoulos GM (2006). Induction of daptomycin heterogeneous susceptibility in Staphylococcus aureus by exposure to vancomycin. Antimicrob Agents Chemother 50: 1581-5. 
12. Nicolsen NC, LeCroy N, Alby K, Martin KE, Laux J \& Lin FC (2013). Clinical outcomes with rapid detection of methicillin-resistant and methicillin susceptible Staphylococcus aureus isolates from routine blood cultures. J Clin Microbiol 51: 4126-9.

13. Lodise TP, McKinnon PS, Swiderski L \& Rybak MJ (2003). Outcomes analysis of delayed antibiotic treatment for hospitalacquired Staphylococcus aureus bacteremia. Clin Infect Dis 36: 1418-23.

14. Hassoun A, Linden PK \& Friedman B (2017). Incidence, prevalence, and management of MRSA bacteremia across patient populations-a review of recent developments in MRSA management and treatment. Critical Care 21: 211.

15. Bauer KA, West JE, Balada-Llasat J-M, Pancholi P, Stevenson KB \& Goff DA (2010). An antimicrobial stewardship program's impact. Clin Infect Dis 51: 1074-80.

16. Palavecino EL (2014). Rapid methods for detection of MRSA in clinical specimens. Methods Mol Biol 1085: 71-83.

17. Kock R, Becker K, Cookson B, van Gemert-Pijnen JE, Harbarth S \& Kluytmans J (2010). Methicillin-resistant Staphylococcus aureus (MRSA): burden of disease and control challenges in Europe. Euro Surveill 15: 19688.

18. Nickerson EK, West TE, Day NP \& Peacock SJ (2009). Staphylococcus aureus disease and drug resistance in resource-limited countries in south and east Asia. Lancet Infect Dis 9: 130-5.

19. Klevens RM, Morrison MA, Nadle J, Petit S, Gershman K \& Ray S (2007). Invasive methicillin-resistant Staphylococcus aureus infections in the United States. JAMA 298: 1763-71.

20. Laupland KB, Lyytikainen O, Sogaard M, Kennedy KJ, Knudsen JD \& Ostergaard C (2013). The changing epidemiology of Staphylococcus aureus bloodstream infection: a multinational populationbased surveillance study. Clin Microbiol Infect 19: 465-71.

21. Dantes R, Mu Y, Belflower R, Aragon D, Dumyati G \& Harrison LH (2013). National burden of invasive methicillin- resistant Staphylococcus aureus infections, United States, 2011. JAMA Intern Med 173: 1970-8.

22. Tenover FC, McDougal LK, Goering RV, Killgore G, Projan SJ \& Patel JB (2006). Characterization of a strain of communityassociated methicillin-resistant Staphylococcus aureus widely disseminated in the United States. J Clin Microbiol 44: 108-18.

23. Weber JT (2005). Community-associated methicillin-resistant Staphylococcus aureus. Clin Infect Dis 4: 269-72.

24. Perveen I, Majid A, Knawal S, Naz I, Sehar S, Ahmed S, \& Raza M (2013). Prevalence and Antimicrobial Susceptibility Pattern of MethicillinResistant Staphylococcus aureus and Coagulase-Negative Staphylococci in Rawalpindi, Pakistan. JAMA 3(1): 198209.

25. Ullah A, Qasim M \& Rahman H (2016). High frequency of methicillinresistant Staphylococcus aureus in Peshawar Region of Pakistan. Springer Plus 5: 600.

26. Musher DM, Lamm N, Darouiche RO, Young EJ, Hamill RJ \& Landon GC (1994). The current spectrum of Staphylococcus aureus infection in a tertiary care hospital. Medicine (Baltimore) 73: 186-208.

27. Waldvogel FA (1995). Staphylococcus aureus (including toxic shock syndrome). In: Mandell GL, Bennett JE, Dolin R, eds. Mandell, Douglas and Bennett's principles and practice of infectious diseases. 4th Ed. Vol. 2. New York: Churchill Livingstone. 1754-77.

28. Mylotte JM, McDermott C \& Spooner JA (1987). Prospective study of 114 consecutive episodes of Staphylococcus aureus bacteremia. Rev Infect Dis 9: 891907.

29. Yzerman EPF, Boelens HAM, Tjhie JHT, Kluytmans JAJW, Mouton JW \& Verbrugh HA (1996). DAPACHE II for predicting course and outcome of nosocomial Staphylococcus aureus bacteremia and its relation to host defense. J Infect Dis 173: 914-9. 
30. Ing MB, Baddour LM \& Bayer AS (1997). Bacteremia and infective endocarditis: pathogenesis, diagnosis, and complications. In: Crossley KB, Archer GL, eds. The staphylococci in human disease. New York: Churchill Livingstone. 331-354.

31. Steinberg JP, Clark CC \& Hackman BO (1996). Nosocomial and communityacquired Staphylococcus aureus bacteremias from 1980 to 1993 : impact of intravascular devices and methicillin resistance. Clin Infect Dis 23: 255-9.

32. Jernigan JA \& Farr BM (1993). Shortcourse therapy of catheter-related Staphylococcus aureus bacteremia: a meta-analysis. Ann Intern Med 119: 30411.

33. Raad II \& Sabbagh MF (1992). Optimal duration of therapy of catheter-related Staphylococcus aureus bacteremia: a study of 55 cases and review.Clin Infect Dis 14: 75-82.

34. Espersen F \& Frimodt-Møller N (1986). Staphylococcus aureus endocarditis: a review of 119 cases. Arch Intern Med 146: 1118-21.

35. Fowler VG Jr, Li J \& Corey GR (1997). Role of echocardiography in evaluation of patients with Staphylococcus aureus bacteremia: experience in 103 patients. $J$ Am Coll Cardiol 30: 1072-8.

36. Sandre RM \& Shafran SD (1996). Infective endocarditis: review of 135 cases over 9 years. Clin Infect Dis 22: 276-86.

37. Chambers HF, Korzeniowski OM \& Sande MA (1983). Staphylococcus aureus endocarditis: clinical manifestations in addicts and nonaddicts. Medicine (Baltimore) 62: 170-7.

38. Marantz PR, Linzer M, Feiner CJ, Feinstein SA, Kozin AM \& Friedland GH (1987). Inability to predict diagnosis in febrile intravenous drug abusers. Ann Intern Med 106: 823-8.

39. Pulvirenti JJ, Kerns E, Benson C, Lisowski J, Demarais P \& Weinstein RA (1996). Infective endocarditis in injection drug users: importance of human immunodeficiency virus serostatus and degree of immunosuppression. $J$ Infect Dis 22: 40-5.

40. Sanabria TJ, Alpert JS, Goldberg R, Pape LA \& Cheeseman SH (1988). Increasing frequency of staphylococcal infective endocarditis: experience at a university hospital, 1981 through 1988. Arch Intern Med 150: 1305-9.

41. Fernández-Guerrero ML, Verdejo C, Azofra J \& de Górgolas M (1995). Hospital-acquired infectious endocarditis not associated with cardiac surgery: an emerging problem. Clin Infect Dis 20: 1623.

42. Fang G, Keys TF \& Gentry LO (1993). Prosthetic valve endocarditis resulting from nosocomial bacteremia: a prospective, multicenter study. Ann Intern Med 119: 560-7.

43. Bone RC (1994). Gram-positive organisms and sepsis. Arch Intern Med 154: 26-34.

44. Casey LC, Balk RA \& Bone RC (1993). Plasma cytokine and endotoxin levels correlate with survival in patients with the sepsis syndrome. Ann Intern Med 119: 771-8.

45. Chesney PJ, Davis JP, Purdy WK, Wand PJ \& Chesney RW (1981). Clinical manifestations of toxic shock syndrome. JAMA 246: 741-8.

46. Wergeland HI, Haaheim LR, Natås OB, Wesenberg F \& Oeding P (1989). Antibodies to staphylococcal peptidoglycan and its peptide epitopes, teichoic acid, and lipoteichoic acid in sera from blood donors and patients with staphylococcal infections. $J$ Clin Microbiol 27: 1286-91.

47. Kali A (2015) Antibiotics and bioactive natural products in treatment of methicillin resistant Staphylococcus aureus: A brief review. Pharmacogn Rev 9(17): 29-34.

48. Humphreys H (2012). Staphylococcus: Skin infections; osteomyelitis; bloodstream infection; food poisoning; foreign body infections; MRSA. In: Greenwod D, Slack RCB,Barer MR, Irving WL. Medical Microbiology EBook: A Guide to Microbial Infections: Pathogenesis, Immunity, Laboratory 
Diagnosis and Control. With student consult Online Access.Elsevier Health Sciences. pp.176-182.

49. Hiramatsu K , Cui L, Kuroda M \& Ito T (2001). The emergence and evolution of methicillin-resistant Staphylococcus aureus. Trends Microbiol 9(10): 486-493.

50. Abdelbary MMH, Basset P, Blanc DS \& Feil EJ (2017). The Evolution and Dynamics of Methicillin-Resistant Staphylococcus aureus.In: Tibayrenc M. Genetics and Evolution of Infectious Diseases( $2^{\text {nd }}$ Ed.). Elsevier: France. pp. 553-572.

51. Chambers HF (1997). Methicillin resistance in staphylococci: molecular and biochemical basis and clinical implications. Clin Microbiol Rev 10 (4): 781-91.

52. Otto M (2012). MRSA virulence and spread. Cell Microbiol 14(10): 1513-1521.

53. Queck, SY Khan BA., Wang R, Bach THL, Kretschmer D, Chen L, Kreiswirth BN, Peschel A, Deleo FR \& Otto M (2009). Mobile genetic element-encoded cytolysin connects virulence to methicillin resistance in MRSA. PLoS Pathog 5(7): e1000533.

54. Renau TE, Hecker SJ \& Lee VJ (1998). Antimicrobial Potentiation Approaches: Targets and Inhibitors. In: Bristol JA. Annual Reports in Medicinal Chemistry. Academic press: London.pp.121-130.

55. Timbrook TT, Morton JB, McConeghy $\mathrm{KW}$, Caffrey AR, Mylonakis E \& LaPlante KL (2017). The effect of molecular rapid diagnostic testing on clinical outcomes in bloodstream infections: a systematic review and metaanalysis. Clin Infect Dis 64: 15-23.

56. Luteijn JM, Hubben GA, Pechlivanoglou P, Bonten MJ \& Postma MJ (2011). Diagnostic accuracy of culture-based and PCR-based detection tests for methicillinresistant Staphylococcus aureus: a metaanalysis. Clin Microbiol Infect 17: 146-54.

57. Nicolsen NC, LeCroy N, Alby K, Martin KE, Laux J \& Lin FC (2013). Clinical outcomes with rapid detection of methicillin-resistant and methicillinsusceptible Staphylococcus aureus isolates from routine blood cultures. J Clin Microbiol 51: 4126-9.

58. Polisena J, Chen S, Cimon K, McGill S, Forward K \& Gardam M (2011). Clinical effectiveness of rapid tests for methicillin resistant Staphylococcus aureus (MRSA) in hospitalized patients: a systematic review. BMC Infect Dis 11: 336.

59. Dhiman N, Trienski TL, DiPersio LP \& DiPersio JR (2013). Evaluation of the BinaxNOW Staphylococcus aureus test for rapid identification of Gram-positive cocci from VersaTREK blood culture bottles. J Clin Microbiol 51: 2939-42.

60. Nonhoff C, Roisin S, Hallin M \& Denis O (2012). Evaluation of Clearview Exact PBP2a, a new immunochromatographic assay, for detection of low-level methicillin-resistant Staphylococcus aureus (LL-MRSA). J Clin Microbiol 50: 3359-60.

61. van Meensel B, Frans J, Laffut W, Van Kerkhoven D, Lemmens A \& Van Schaeren J (2011). Multicenter validation of the Clearview Exact PBP2a test. In: 21st European Congress of Clinical Microbiology and Infectious Diseases. Milan, Italy.

62. Jevons MP (1961) Celbenin -resistant Staphylococci. Br Med J 1(5219): 124 125.

63. Hemaiswarya S, Kruthiventi AK \& Doble $M$ (2008). Synergism between natural products and antibiotics against infectious diseases. Phytomedicine 15(8): 639-52.

64. Mintah SO, Asafo-Agyei T, Archer M-A, Junior PA-A, Boamah D, Kumadoh D, Appiah A, Ocloo A, Boakye YD \& Agyare C (2019). Medicinal Plants for Treatment of Prevalent Diseases. Pharmacogn Med Plants: 1-19.

65. Shrestha PM \& Dhillion SS (2003). Medicinal plant diversity and use in the highlands of Dolakha district, Nepal. $J$. Ethnopharmacol 86(1): 81-96.

66. Iwu MM, Duncan AR \& Okunji CO (1999). New Antimicrobials of Plant Origin. In: Janick J. Perspectives on new crops and new uses. ASHS Press: Alexandria, VA. pp. 457-462.

67. Khan MF, Tang H, Lyles JT, Pineau R, Mashwani ZUR \& Quave CL (2018). 
Antibacterial properties of medicinal plants from Pakistan against multidrugresistant ESKAPE pathogens. Front Pharmacol 9: 815.

68. Duraipandiyan V, Ayyanar M \& Ignacimuthu S (2006). Antimicrobial activity of some ethnomedicinal plants used by Paliyar tribe from Tamil Nadu, India. BMC Complement Altern Med 6: 35.

69. Cos P, Vlietinck AJ, Berghe DV \& Maes L (2006). Anti-infective potential of natural products: how to develop a stronger in vitro 'proof-of-concept. $J$. Ethnopharmacol 106(3): 290-302.

70. Wilkins KM \& RG Board (1989). Natural antimicrobial systems. In: Gould GW. Mechanisms of action of food preservation procedures. London: Elsevier Appl Sci 285-362.

71. Borris RP (1996). Natural products research: perspectives from a major pharmaceutical company. Ethnopharmacol 51 (1-3): 29-38.

72. Zouhir, A., Jridi, T., Nefzi A, Hamida JB \& Sebei K (2016). Inhibition of methicillin-resistant Staphylococcus aureus (MRSA) by antimicrobial peptides (AMPs) and plant essential oils. Pharm Biol 54(12): 3136-3150.

73. Ríos JL \& Recio MC (2005). Medicinal plants and antimicrobial activity. $J$ Ethnopharmacol 100(1-2): 80-84.

74. Chew YL, Mahadi AM, Wong KM \& Goh JK (2018). Anti-methicillin-resistance Staphylococcus aureus (MRSA) compounds from Bauhinia kockiana Korth. And their mechanism of antibacterial activity BMC Complement Altern Med 18(1): 70.

75. Voravuthikunchai SP \& Kitpipit L (2005). Activity of medicinal plant extracts against hospital isolates of methicillinresistant Staphylococcus aureus. Clin Microbiol Infect 11(6): 510-512.

76. Li J, Liu D, Tian X, Koseki S \& Chen S (2019). Novel antibacterial modalities against methicillin resistant Staphylococcus aureus derived from plants. Crit Rev Food Sci Nutr 59(sup1): S153-S161.

77. Rueda RY (2013). Natural Plant Products Used against Methicillin-Resistant
Staphylococcus aureus. In Rai MK, Kon KV. Fighting Multidrug Resistance with Herbal Extracts, Essential Oils and their Components. Academic Press 11-22.

78. Elgayyar M, Draughon FA, Golden DA \& Mount JR (2001). Antimicrobial Activity of Essential Oils from Plants against Selected Pathogenic and Saprophytic Microorganisms. J Food Prot 64(7): 1019-1024.

79. Tongnuanchan P \& Benjakul S (2014). Essential oils: extraction, bioactivities, and their uses for food preservation. $J$ Food Sci 79(7): 1231-49.

80. Helander IM, Alakomi HL, K. Latva-Kala K, T. Mattila-Sandholm T, Pol I, Smid EJ, Gorris LGM \& Wright AV (1998). Characterization of the action of selected essential oil components on Gramnegative bacteria. Agric. Food Chem 46(9): 3590-3595.

81. Olajuyigbe O \& Ashafa A (2014). Chemical Composition and Antibacterial Activity of Essential Oil of Cosmos bipinnatus cav. Leaves from South Africa. Iran J Pharm Res 13(4): 1417-1423.

82. Carson CF, Cookson BD, Farrelly HD \& Riley TV (1995). Susceptibility of methicillin-resistant Staphylococcus aureus to the essential oil of Melaleuca alternifolia. $J$ Antimicrob Chemother 35(3): 421-4.

83. Edwards-jones V, Buck R, Shawcross SG, Dawson MM \& Dunn K (2004). The effect of essential oils on methicillinresistant Staphylococcus aureus using a dressing model. Burns 30(8): 772-777.

84. Uzair B, Niaz N, Bano A, Khan BA, Zafar N, Iqbal M, Tahira R \& Fasim F (2017). Essential oils showing in vitro anti MRSA and synergistic activity with penicillin group of antibiotics Pak J Pharm Sci 30(5): 1997-2002.

85. Muthaiyan A, Biswas D, Crandall PG, Wilkinson BJ \& Ricke SC (2012). Application of orange essential oil as an antistaphylococcal agent in a dressing model. BMC Complement Altern Med 12: 125.

86. Aelenei P, Rimbu CM, Guguianu E, Dimitriu G, Aprotosoaie AC, Brebu M, Horhogea CE \& Miron A (2019). 
Coriander essential oil and linalool interactions with antibiotics against Grampositive and Gram-negative bacteria. Lett Appl Microbiol 68(2): 156-164.

87. Warnke PH, Lott AJS, Sherry E, Wiltfang J \& Podschun R (2013). The ongoing battle against multi-resistant strains: Invitro inhibition of hospital-acquired MRSA, VRE, Pseudomonas, ESBL E. coli and Klebsiella species in the presence of plant-derived antiseptic oils. $J$ Craniomaxillofac Surg 41(4): 321-326.

88. Oliva A, Costantini S, Angelis MD, Garzoli S, Božović M, Mascellino MT, Vullo V \& Ragno R (2018). High Potency of Melaleuca alternifolia Essential Oil against Multi-Drug Resistant GramNegative Bacteria and MethicillinResistant Staphylococcus aureus. Mol 23(10): 2584.

89. Tohidpour A, Sattari M, Omidbaigi R, Yadegar A \& Nazemi J (2010). Phytomedicine Antibacterial effect of essential oils from two medicinal plants against Staphylococcus aureus(MRSA). Phytomed 17(2):142-145.

90. Gadisa E, Weldearegay G, Desta K, Tsegaye G, Hailu S, Jote K \& Takele A (2019). Combined antibacterial effect of essential oils from three most commonly used Ethiopian traditional medicinal plants on multidrug resistant bacteria. BMC Complement Altern Med 19(1): 24.

91. Marchese A, Arciola CR, Coppo E, Barbieri R, Barreca D, Chebaibi S, Sobarzo-Sánchez E, Nabavi SF, Nabavi SM \& Daglia M (2018). The natural plant compound carvacrol as an antimicrobial and anti-biofilm agent: mechanisms, synergies and bio-inspired anti-infective materials. Biofouling 34(6): 630-656.

92. Kon KV \& Rai MK (2012). Plant essential oils and their constituents in coping with multidrug-resistant bacteria. Expert Rev Anti Infect Ther 10(7): 775-790.

93. Zhong YC, ZhiYing C, Ying Ying G, Ting L, KeXin G \& LiZi Y (2018). Antibacterial mechanism of thymol on methicillin-resistant Staphylococcus aureus (MRSA). J South China Agric Univ 39(6): 18-23.
94. Yuan Z, Dai Y, Ouyang P, Rehman T, Hussain S, Zhang T, Yin Z, Fu H, Lin J, He C, Lv C, Liang X, Shu G, Song X, Li L, Zou Y \& Yin L (2020). Thymol inhibits biofilm formation, eliminates pre- existing biofilms, and enhances clearance of methicillin-resistant Staphylococcus aureus (MRSA) in a mouse peritoneal implant infection model. Microorganisms 8(1): 99.

95. Goncalves O, Pereira R, Goncalves FJM, Mendo S, Manuel A, Coimbra MA \& Rocha SM (2011). Evaluation of the mutagenicity of sesquiterpenic compounds and their influence on the susceptibility towards antibiotics of two clinically relevant bacterial strains. Mutat Res Genet Toxicol Environ Mutagen 723(1): 18-25.

96. Cowan MM (1999). Plant Products as Antimicrobial Agents. 12(4): 564-582.

97. Tsuchiya H, Sato M, Miyazaki T, Fujiwara S, Tanigaki S, Ohyama M, Tanaka T \& Iinuma M (1996). Comparative study on the antibacterial activity of phytochemical flavanones against methicillin-resistant Staphylococcus aureus. J Ethnopharmacol 50(1): 27-34.

98. Taylor PW, Hamilton-Miller JMT \& Stapleton PD (2005). Antimicrobial properties of green tea catechins. Food Sci Technol Bull 2: 71-81.

99. Qin R, Xiao K, Li B, Jiang W, Peng W \& Zheng J (2013). The Combination of Catechin and Epicatechin Gallate from Fructus Crataegi Potentiates $\beta$-Lactam Antibiotics Against Methicillin-Resistant Staphylococcus aureus (MRSA) in Vitro and in Vivo. Int J Mol Sci 14(1): 18021821.

100. Stapleton PD, Shah S, Hamilton-miller JMT, Hara Y, Nagaoka Y, Kumagai A, Uesato S \& Taylor PW (2004). AntiStaphylococcus aureus activity and oxacillin resistance modulating capacity of 3-O-acyl-catechins. Int. J. Antimicrob. Agents 24: 374-380.

101. Adnan SNA, Ibrahim N \& Yaacob WA (2017). Disruption of methicillin-resistant Staphylococcus aureus protein synthesis by tannins. Germs 7(4): 186-192. 
102. Griffin SG, Wyllie SG, Markham JL \& Leach DN (1999). The role of structure and molecular properties of terpenoids in determining their antimicrobial activity. Flavour Fragr J 14(5): 322-332.

103. Gupta VK, Tiwari N, Gupta P, Verma S, Pal A, Srivastava SK \& Darokar MP (2016). A clerodane diterpene from Polyalthia longifolia as a modifying agent of the resistance of methicillin resistant Staphylococcus aureus. Phytomedicine 23(6): 654-61.

104. Pervaiz A, Khan R, Anwar F, Mushtaq G, Kamal MA \& Khan H (2016). Alkaloids: An Emerging Antibacterial Modality Against Methicillin Resistant Staphylococcus aureus. Curr Pharm Des 22(28): 4420-4429.

105. Mahizan NA, Yang SK, Moo CL, Song AAL, Chong CM, Chong CW, Abushelaibi A, Lim SHE \& Lai KS (2019). Terpene Derivatives as a Potential Agent against Antimicrobial Resistance (AMR) Pathogens Mol 24(14): 2631.

106. Anyanwu MU \& Okoye RC (2017). Antimicrobial activity of Nigerian medicinal plants. J. Intercult. Ethnopharmacol 6(2): 240-259.

107. Werf MJVD, de Bont, JAM \& Leak DJ (1997). Opportunities in microbial biotransformation of monoterpenes.In: Berger R.G. et al. Biotechnology of Aroma Compounds. Advances in Biochemical Engineering/Biotechnology. Springer: Berlin, Heidelberg 147-177.

108. Vuuren SFV (2008). Antimicrobial activity of South African medicinal plants. J Ethnopharmacol 119(3): 462-472.

109. Riaz N, Faheem SM \& Ahmad MU (2020). A Thematic Review on Potential Antimicrobial Potential Applications of Bacteriocins from Lactic Acid Bacteria. Eur J Pharm Med Res 7(11): 246-257.

110. Okuda KI, Zendo T, Sugimoto S, Iwase T, Tajima A, Yamada S, Sonomoto K \& Mizunoe Y (2013). Effects of bacteriocins on methicillin-resistant Staphylococcus aureus biofilm. Antimicrob. Agents Chemother 57(11): 5572-5579.

111. Meade E., Slattery MA \& Garvey M (2020). Bacteriocins, potent antimicrobial peptides and the fight against multi drug resistant species: Resistance is futile? Antibiotics (Basel) 9(1): 32.

112. Kraaij CV, Vos WMD, Siezen RJ \& Kuipers OP (1999). Lantibiotics: biosynthesis, mode of action and applications., Nat Prod Rep 16(5): 575-87.

113. Aween MM, Hassan Z., Muhialdin BJ, Eljamel YA, Al-Mabrok A.S.W \& Lani MN (2012). Antibacterial Activity of Lactobacillus acidophilus Strains Isolated from Honey Marketed in Malaysia against Selected Multiple Antibiotic Resistant (MAR) Gram-Positive Bacteria. J Food Sci 77(7): M364-M371.

114. Isnansetyo A \& Kamei Y (2003). MC21A, a Bactericidal Antibiotic Produced by a New Marine Bacterium, Pseudoalteromonas phenolica sp. nov. OBC30T, against Methicillin-Resistant Staphylococcus aureus. Antimicrob Agents Chemother 47(2): 480-488.

115. Karska-Wysocki B, Bazo M \& Smoragiewicz W (2010). Antibacterial activity of Lactobacillus acidophilus and Lactobacillus casei against methicillinresistant Staphylococcus aureus (MRSA). Microbiol Res 165(8): 674-86.

116. Nascimento JS, Ceotto H, Nascimento SB, Giambiagi-DeMarval M, Santos KRN \& Bastos MCF (2006). Bacteriocins as alternative agents for control of multiresistant staphylococcal strains. Lett Appl Microbiol 42: 215-221.

117. Mahlapuu M, Håkansson J, Ringstad L \& Björn C (2016). Antimicrobial peptides: An emerging category of therapeutic agents. Front Cell Infect Microbiol 6: 194.

118. Malmsten M (2015). Interactions of Antimicrobial Peptides with Bacterial Membranes and Membrane Components. Curr Top Med Chem 16(1): 16-24.

119. Sylvia S, Wang M, Gao R, Teng P, Odom $\mathrm{T}$, Zhang E, Xu H \& Cai J (2020). Lipidated $\alpha /$ Sulfono- $\alpha$-AA heterogeneous peptides as antimicrobial agents for MRSA. Bioorg Med Chem 28(1): 115241.

120. Fritsche TR, Rhomberg PR, Sader HS \& Jones RN (2008). In vitro activity of omiganan pentahydrochloride tested against vancomycin-tolerant, intermediate, and -resistant 
Staphylococcus aureus.Diagn Microbiol Infect Dis 60(4): 399-403.

121. Lee DS, Kim YM, Lee MS, Ahn CB, Jung WK \& JY J (2010). Synergistic effects between aminoethyl-chitosans and $\beta$ lactams against methicillin-resistant Staphylococcus aureus (MRSA). BioorganicMed Chem Lett 20(3): 975978.

122. Xiong F, Dai X, Li YX, Wei R, Li A, Wang Y \& Chen Z (2019). Effects of the antimicrobial peptide L12 against multidrug-resistant Staphylococcus aureus. Mol Med Rep 19(4): 3337-3344

123. Gutiérrez D, Fernández L, Rodríguez A \& García P (2019). Role of Bacteriophages in the Implementation of a Sustainable Dairy Chain. Front Microbiol 10: 12.

124. Bondy-denomy J \& Davidson AR (2014). When a Virus is not a Parasite: The Beneficial Effects of Prophages on Bacterial Fitness. J Microbiol 52(3): 235242.

125. Verstappen KM, Tulinski P, Duim B, Fluit AC \& Carney J (2016). The Effectiveness of Bacteriophages against MethicillinResistant Staphylococcus aureus ST398 Nasal Colonization in Pigs. PLoS One 11(8): 160-242.

126. Duckworth DH (1976). Who Discovered Bacteriophage? Bacteriol Rev 40(4): 793802.

127. Golkar Z, Bagasra O \& Pace DG (2014). Bacteriophage therapy: a potential solution for the antibiotic resistance crisis. J Infect Dev Ctries 8(2): 129-136.

128. Sulakvelidze A, Alavidze Z \& Morris JJG (2001). MINIREVIEW Bacteriophage Therapy. Antimicrob Agents Chemother 45(3):649-659.

129. Skurnik M \& Strauch E (2006). Phage therapy: Facts and fiction. Int $J$ Med Microbiol 296(1): 5-14.

130. Hallajzadeh M, Mojtahedi A, Mahabadi VP \& Amirmozafari N (2019). Isolation and In Vitro Evaluation of Bacteriophage against

Methicillin-Resistant Staphylococcus aureus (MRSA) from Burn Wounds. Arch Clin Microbiol 10(4): 98.

131. Şahİn F, Karasartova D, Özsan TM, Gerçeker D \& Kiyan M (2013).
Identification of a Novel Lytic Bacteriophage Obtained from Clinical MRSA Isolates and Evaluation of Its Antibacterial Activity. Mikrobiyol Bul 47(1): 27-34.

132. Tan CS, Aqiludeen NA, Tan R, Gowbei A, Mijen B, Louis SR \& Ibrahim SF (2020). Could bacteriophages isolated from the sewage be the solution to methicillinresistant Staphylococcus aureus? Med J Malaysia 75(2): 110-116. Jia J, Liu Q, Wang R, Luo T, Guo X, Xu M, Yin Q, Wang X, Zhou M, Li M \& He P (2020). Identification of a novel phage targeting methicillin-resistant $S$. aureus In vitro and In vivo. Microb Pathog 149: 104317.

133. Joerger RD (2001). Alternatives to Antibiotics: Bacteriocins, Antimicrobial Peptides and Bacteriophages. Poult Sci 82(4): 640-647.

134. Loeffler JM, Nelson D \& Fischetti VA (2001). Rapid killing of Streptococcus pneumoniae with a bacteriophage cell wall hydrolase. Sci 294(5549): 2170-2172.

135. Engler AC, Wiradharma N, Ong ZY, Coady DJ, Hedrick JL \& Yang YY (2012). Emerging trends in macromolecular antimicrobials to fight multi-drug-resistant infections. Nano Today 7(3): 201-222.

136. Labruère R, Sona AJ \& Turos E (2019). Anti-Methicillin-Resistant

Staphylococcus aureus Nanoantibiotics Front Pharmacol 10: 1121.

137. Feng QL, Wu J, Chen GQ, Cui FZ, Kim TN \& Kim JO (2000). A mechanistic study of the antibacterial effect of silver ions on Escherichia coli and Staphylococcus aureus. J Biomed Mater Res 52(4): 662-668.

138. Liau SY, Read DC, Pugh WJ, Furr JR \& Russell AD (1997). Interaction of silver nitrate with readily identifiable groups: relationship to the antibacterial action of silver ions. Lett Appl Microbiol 25(4): 279-283.

139. Djokić SS (2004). Deposition of silver oxysalts and their antimicrobial properties. J Electrochem Soc 151(6): C359.

140. Karlsson HL, Gustafsson J, Cronholm P \& Moller L (2009). Size-dependent toxicity of metal oxide particles - a comparison 
between nano- and micrometer size. Toxicol Lett 188(2): 112-118.

141. Lynch I \& Dawson KA (2008). Proteinnanoparticle interactions Nano Today 3(12): 40-47.

142. Xu ZP, Zeng QH, Lu GQ \& Yu AB (2006). Inorganic nanoparticles as carriers for efficient cellular delivery. Chem Eng Sci 61(3): 1027-1040.

143. Bugli, F, Cacaci M., Palmieri V, Santo RD, Torelli R, Ciasca G, Vito MD, Vitali A, Conti C, Sanguinetti M, De Spirito M \& Papi M (2018). Curcumin-loaded graphene oxide flakes as an effective antibacterial system against methicillinresistant staphylococcus aureus. Interface Focus 8(3): 20170059.

144. Middleton JR (2008). Staphylococcus aureus antigens and challenges in vaccine development. Expert Rev Vaccines 7(6): 805-815.

145. Ohwada, A, Sekiya M, Hanaki H, Arai KK, Nagaoka II, Hori S, Tominaga S, Hiramatsu K \& Fukuchi Y (1999). DNA vaccination by mecA sequence evokes an antibacterial immune response against methicillin-resistant Staphylococcus aureus. J Antimicrob Chemother 44(6): 767-74.

146. Parker D (2018). A live vaccine to staphylococcus aureus infection. Virulence 9(1): 700-702.

147. Singh S, Wang M, Gao R, Teng P, Odom $\mathrm{T}$, Zhang E, Xu H \& Cai J (2020). Lipidated $\alpha /$ Sulfono- $\alpha$-AA heterogeneous peptides as antimicrobial agents for MRSA. Bioorg Med Chem 28(1): 115241.
148. Chongsiriwatana, NP, Patch JA, Czyzewski AM, Dohm MT, Ivankin A, Gidalevitz D, Zuckermann RN \& Barron AE (2008). Peptides that mimic the structure, function, and mechanism of helical antimicrobial peptides. Proc Natl Acad Sci U S A 105(8):2794-2799.

149. Calfee DP, Salgado CD, Milstone AM, Harris AD, Kuhar DT \& Moody J (2014). Strategies to prevent methicillin-resistant Staphylococcus aureus transmission and infection in acute care hospitals: 2014 update. Infect Control Hospital Epidemiol 35: 772-96.

150. Marimuthu K, Pittet D \& Harbarth S (2014). The effect of improved hand hygiene on nosocomial MRSA control. Antimicrob Resist Infect Control 3: 34.

151. Jinadatha C, Quezada R, Huber TW, Williams JB, Zeber JE \& Copeland LA (2014). Evaluation of a pulsed-xenon ultraviolet room disinfection device for impact on contamination levels of methicillin-resistant Staphylococcus aureus. BMC Infect Dis 14: 187.

152. Salgado CD, Sepkowitz KA, John JF, Cantey JR, Attaway HH \& Freeman KD (2013). Copper surfaces reduce the rate of healthcare-acquired infections in the intensive care unit. Infect Control Hosp Epidemiol 34: 479-86.

153. Kavanagh KT, Calderon LE, Saman DM \& Abusalem SK (2014). The use of surveillance and preventative measures for methicillin-resistant Staphylococcus aureus infections in surgical patients. Antimicrob Resist Infect Control 3: 18. 